\title{
Noncompliance with SEC regulations: evidence from timely loan disclosures
}

\author{
Judson Caskey ${ }^{1}$ (D) Kanyuan Huang $^{1} \cdot$ Daniel Saavedra $^{1}$
}

Accepted: 16 August 2021/Published online: 22 September 2021

(C) The Author(s) 2021

\begin{abstract}
We use required 8-K filings around major borrowings to shed light on firms' choices of whether to comply with SEC disclosure rules. Exploiting within-firm variation, we find that firms are more likely to hide loans with high spreads and tight financial covenants. We further find that firms appear to exploit the ambiguity of the definition of materiality, as they are more likely to selectively disclose (hide) "immaterial" loans when interest rates are low (high). Firms are less likely to hide loans when investors anticipate borrowing during asset acquisition, when firms are followed by more equity analysts or receive more investor attention, and when the firms' stock prices are more volatile. Lastly, we provide evidence that the SEC does not rigorously enforce compliance with 8-K loan disclosures.
\end{abstract}

Keywords Disclosure $\cdot$ Bank loans $\cdot$ SEC monitoring $\cdot$ Form $8-\mathrm{K} \cdot$ Materiality

JEL classification $\mathrm{G} 21 \cdot \mathrm{G} 28 \cdot \mathrm{G} 32 \cdot \mathrm{H} 25 \cdot \mathrm{H} 32$

\section{Introduction}

Firms face numerous Securities and Exchange Commission (SEC) requirements to disclose material information to investors and other interested parties. As is the case with any mandate, firms choose whether to comply. Firms can avoid disclosure by obtaining permission to redact information from the SEC (Verrecchia and Weber 2006)

Judson Caskey

judson.caskey@anderson.ucla.edu

Kanyuan Huang

kanyuan.huang.phd@anderson.ucla.edu

Daniel Saavedra

daniel.saavedra@anderson.ucla.edu

1 UCLA Anderson School of Management, Los Angeles, CA, USA 
or by simply failing to comply with reporting requirements and facing the costs of doing so.

In this study, we examine firms' compliance with the SEC requirement to make timely disclosures of material debt agreements through an $8-\mathrm{K}$ filing, which became effective on August 23, 2004. Because lenders privately acquire information on borrowers, loan spreads can reflect information not otherwise impounded into stock price (Plumlee et al. 2015). An 8-K filing provides salient information about a loan. In contrast, when firms fail to file an $8-\mathrm{K}$ for a borrowing, later financial reports provide less timely and salient information about the loan. If the firm discloses the loan in a later $10-\mathrm{K}$ or $10-\mathrm{Q}$, investors may not attend to the disclosure because their attention is spread across the wealth of content in a given quarterly or annual report (Hirshleifer and Teoh 2003). Furthermore, firms may fail to disclose the loan at all, in which case investors see only indirect evidence of the loan via changes in debt balances, interest expense, and activity on the cash flow statement. In all of these cases, the failure to file an $8-\mathrm{K}$ obscures the loan characteristics and makes it less likely that investors will impound them into stock price. This can, at least temporarily, benefit managers if the loan characteristics reveal negative information about the firm. ${ }^{1}$ For example, managers might want to delay disclosure of high borrowing costs because it could send a negative signal to stakeholders.

Our empirical tests utilize Dealscan to gain ex post visibility into loans that firms obtained but may not have disclosed in Form $8-\mathrm{K}$ at the time of loan issuance. In particular, Dealscan collects loan information directly from borrowers and lenders, in addition to collecting information from SEC fillings such as10-Ks, 10-Qs, 8-Ks, and registration statements. ${ }^{2}$ Our tests compare loans disclosed contemporaneously in Form $8-\mathrm{K}$ to ones the same firm either failed to disclose or disclosed later in annual or quarterly reports (10-K or 10-Q, respectively). Exploiting within-firm variation, we find a robust negative relation between loan spreads and disclosure compliance. We interpret this as firms being reluctant to disclose loans with higher-than-expected spreads, which may indicate negative news about the firm. We characterize this as a relative comparison because our use of both loan spreads and year fixed effects controls for the overall level of interest rates, and our use of firm fixed effects controls for firms' typical spreads. If firms mistakenly omit Form 8-K disclosures or only omit immaterial loans, we would expect no association between nondisclosure and loan spreads.

Firms fail to file Form $8-\mathrm{K}$ for about $18 \%$ of loans in our sample. Of those, firms disclose about $75 \%$ of the loans in a subsequent $10-\mathrm{K}$ or $10-\mathrm{Q}$ and never directly disclose the remaining $25 \%$. We find a robust positive association between loan spread and nondisclosure, consistent with firms withholding adverse information. Put differently, the average firm is more likely to disclose loans when borrowing costs are lower and to hide loans when borrowing costs are higher. Moreover, we find that this result is stronger for "immaterial" loans, which suggests that firms may exploit the ambiguous definition of materiality. To further strengthen our main inference, we conduct three robustness tests. First, we take advantage of the fact that firms sometimes hide loans until a subsequent $10-\mathrm{K} / \mathrm{Q}$ release and other times never disclose the loan. We find

\footnotetext{
${ }^{1}$ In an appendix, we use a model to formally develop predictions.

${ }^{2}$ Thomson Reuters, Dealscan's owner, uses this information in its published lender rankings, which gives lenders strong incentives to report loans to Dealscan.
} 
stronger results for firms with more opaque disclosure (i.e., firms that never disclose the loan). Second, we find similar results when we exclude loans that are smaller than 5\% of total assets, suggesting that our results are not driven by immaterial loans. Third, based on the notion that misclassified 8-Ks reduce investor attention (Bird et al. 2018), we also find a positive relation between loan spreads and misclassification of 8-Ks.

We conduct two cross-sectional tests of the relation between loan spreads and nondisclosure. Consistent with competition increasing the cost of revealing private information (Verrecchia and Weber 2006), we find a stronger relation between spreads and nondisclosure in highly competitive industries (those above the sample median Herfindahl index) than in less competitive industries. We find a similar relation between loan spreads and nondisclosure among firms with Big 4 versus non-Big 4 auditors, and a stronger negative association between loan amount and nondisclosure among firms with Big 4 auditors. This suggests that audit quality impacts the disclosure of large loans, but auditors largely ignore the informational impact of loan spreads.

In additional tests, we examine other drivers of nondisclosure of loans in 8-Ks. First, we find that firms more often disclose loans when investors are less likely to associate nondisclosure of a loan with nonexistence of a loan. Specifically, we find that firms withhold disclosure less often around acquisitions that presumably increase the expectation that the firm borrowed. We also find that firms withhold disclosure less often when they are followed by more analysts, receive more investor attention, and experience high volatility, consistent with a lower benefit of nondisclosure when investors pay greater attention to financial reports and thus are able to infer the presence of undisclosed loans. Second, we find a positive association between the number of tight loan covenants and nondisclosure, indicating that companies may wish to avoid revealing contracts for which they have a high risk of technical default.

Finally, we shed light on the costs and benefits of noncompliance. First, of the 12,735 SEC comment letters to firms in our sample, only 74 refer to loan disclosures in general (e.g., missing loan exhibits or schedules), and only one specifically refers to the failure to disclose a loan in an 8-K. Overall, this evidence suggests that the SEC does not closely monitor loan related disclosures. The apparent small cost of noncompliance suggests that firms will fail to file an $8-\mathrm{K}$ with adverse loan information even if the nonfiling conveys only a small benefit, such as delaying or slightly reducing the market's ultimate impounding of the news. We find evidence of a temporary share price benefit from nondisclosure, in that firms that hide loans enjoy higher stock returns in the month following the undisclosed loan issuance but these higher returns reverse within the next 3 months. Further, we find that the opacity of loan disclosure is positively associated with spreads on subsequent loans. This is consistent with nondisclosure impacting the debt market.

This paper contributes primarily to the disclosure literature. ${ }^{3}$ Most of the prior literature focuses on either voluntary disclosure (see review in Beyer et al. (2010)) or on the quality of mandatory disclosures (see review in Dechow et al. (2010)). This paper takes a different angle that focuses on withholding of mandatory disclosures, as opposed to distorting mandatory disclosures or withholding voluntary disclosures. We provide direct evidence that managers withhold bad news (i.e., high spread loans), consistent with Kothari et al.'s (2009) findings that firms delay bad news. We

\footnotetext{
${ }^{3}$ In Section 2, we elaborate on this paper's relation to the literature.
} 
document that firms withhold loan disclosure even after it is mandated by the regulator, and that the SEC review process does not detect this noncompliance. Moreover, we find that firms appear to exploit the ambiguous definition of materiality. These findings shed light on the efficacy of 8-K regulation.

\section{Background}

\subsection{Related literature}

This study relates to prior work on redacted disclosure, which focuses on omitting disclosure with permission from the SEC. In contrast to our setting with nondisclosure, when firms redact portions of a disclosure, the SEC is aware of the nondisclosure and corroborates that it stems from the desire to protect proprietary information. This literature finds that firms more often redact information when they face high competition (Verrecchia and Weber 2006; Boone et al. 2016). Saavedra (2019a) finds evidence that lenders influence redaction of loan terms when it helps them preserve their information advantage, à la Rajan (1992). Tian and Yu (2018) and Chen et al. (2019) find that firms redact information to protect proprietary information in product markets. Instead of redactions obtained with permission from regulators, this study examines the outright omission of required disclosures.

Prior studies on corporate disclosure have examined factors associated with news that is disclosed (e.g., Skinner 1994, 1997) or disclosed with a delay (Kothari et al. 2009). With respect to 8-K disclosure, Carter and Soo (1999) examine the timing and information content of 8-K filings before the 8-K regulation was introduced in 2004. They find that over $26 \%$ of the 8 -Ks are filed after the deadline and that larger firms are more likely to file $8-\mathrm{Ks}$ on time. Further, they find that timely filing of $8-\mathrm{Ks}$ is associated with significant market reaction, suggesting that 8 -Ks contain relevant information. Lerman and Livnat (2010) study the 8-K filings after the 2004 regulation. They find that most firms (95\%) comply with the regulation by filing 8 -Ks within four business days, and they document significant trading volume and stock returns after 8K filings. Li (2013) studies firms' incentives to voluntarily accelerate the disclosure of material contracts in 8-Ks. He finds that manager credibility, litigation concerns, and proprietary costs are associated with accelerated disclosure of contracts. He also finds that these incentives play a less important role after the 2004 SEC mandate. Our paper differs from the prior studies on 8 - $\mathrm{K}$ disclosure in that we study the incentives and consequences of the omission of required disclosures. The loan data in Dealscan provide a direct measure of disclosable borrowings, against which we can compare what firms actually disclose. In addition, we examine the regulatory consequences of noncompliance and whether firms exploit the ambiguous definition of materiality.

Lastly, our study relates to research on the SEC review process. Prior studies focus on the consequences of the SEC review process. Several of these studies show that SEC comment letters increase reporting quality and reduce information asymmetry (Bens et al. 2016; Cunningham et al. 2019; Johnston and Petacchi 2017; Kubick et al. 2016). One exception is Robinson et al. (2011), who show that SEC comment letters regarding CEO compensation do not reduce excess CEO pay. Other studies focus on the determinants of the SEC review process (Cassell et al. 2013; Ege et al. 2019; Gunny 
and Hermis 2019; Heese et al. 2017). Our study differs from the prior literature in that we examine whether the SEC monitors noncompliance with mandatory disclosures.

\subsection{The new form 8-K requirements}

Beginning in August 2004, the SEC requires that firms file a Form 8-K disclosure within four business days of entering into a material debt contract. ${ }^{4}$ The Form $8-\mathrm{K}$ filing must be under item 1.01 (material contract) or item 2.03 (direct financial obligation or off-balance sheet arrangement). The borrower can, however, request that the SEC allow it to redact proprietary information contained within the contract. By redacting data, firms are able to avoid disclosing information that they deem proprietary, thereby reducing the overall amount of information that is disclosed to the public. These requests of confidential treatment are usually approved by the SEC and are relatively inexpensive. ${ }^{5}$ However, Verrecchia and Weber (2006) show that redaction is associated with a larger adverse selection component of bid-ask spreads.

Firms primarily face potential regulatory costs for failing to file timely 8 -K disclosures. The SEC periodically reviews public firms' filings and issues comment letters to noncompliant firms. ${ }^{6}$ In the case of 8-K filings, the SEC provides a limited safe harbor related to 10 (b) and 10(b)-5 litigation for a failure to timely file a Form 8 -K with respect to item 1.01, 1.02, and a few other items. This safe harbor does not shield companies from liabilities under sections 13 and 15(d) of the Securities Exchange Act of 1934, and it does not affect the SEC's ability to enforce the 8-K filing requirement. ${ }^{7}$ In November 2014 and September 2016, the SEC announced enforcement actions against 14 companies for failing to file 8-Ks related to item 1.01 (material contract) and item 3.02 (unregistered equity sales). ${ }^{8}$ All 14 are small companies that are traded on the Pink Sheets and not part of our sample. Thirteen of the 14 companies settled with the SEC by paying a small fine. One company (Accel Brands) faces possible suspension for not only failing to file 8-Ks but also failing to respond to the SEC's comments. ${ }^{9}$

Some practitioners believe that the SEC does not dedicate much time and resources to monitoring 8-K filings. For instance, Laura Anthony, the founding partner of Legal \& Compliance LLC, writes, "The SEC rarely takes enforcement action or expends time or resources on investigating the failure to file an $8-\mathrm{K}$. When such issues arise, it is usually in connection with a routine review of a company's SEC reports or as part of the comment and review process associated with the filing of a registration statement. All reports filed with the SEC are subject to SEC review and comment, and the

\footnotetext{
${ }^{4}$ Per discussions with SEC personnel, this includes activities such as establishing a credit line, even before drawing on it, and obtaining loans.

${ }^{5}$ External lawyer fees are around \$5000-\$20,000 for each request (Saavedra 2019a).

${ }^{6}$ Per discussions with SEC personnel, the filing review serves as the primary means of enforcing compliance with 8 -K filing requirements. See https://www.sec.gov/divisions/corpfin/cffilingreview.htm.

${ }^{7} \mathrm{https}: / / w w w . s e c . g o v / r u l e s /$ final/33-8400.htm.

${ }^{8}$ For the 2014 cases: https://www.sec.gov/news/press-release/2014-248. For the 2016 cases: Connexus Corporation, SEC Rel. No. 78934 (Sept. 26, 2016); Bluefire Renewables, Inc., SEC Rel. No. 78955 (Sept. 27, 2016); and Elray Resources, Inc., SEC Rel. No. 79011 (Sept. 30, 2016). Accel Brands, Inc., SEC Rel. No. 78933

${ }^{9}$ https://www.sec.gov/litigation/admin/2016/34-78933.pdf
} 
Sarbanes-Oxley Act requires that the SEC undertake some level of review of every reporting company at least once every three years." ${ }^{10}$ Gunny and Hermis (2019) show that the SEC faces resource constraints and issues fewer comment letters when busier.

\subsection{The syndicated loan market}

The syndicated loan market is a primary source of financing for corporations (Gorton and Winton 2003). Since the late 1980s, this market has experienced exponential growth (Sufi 2007; Wittenberg-Moerman 2008). Members of a syndicate fall into one of two groups: lead arrangers and participant lenders. Lead arrangers take on the primary information collection and monitoring responsibilities (see Sufi (2007) and Standard and Poor's (2014) for more details about due diligence at loan inception). The lead arranger(s) and the borrower negotiate an information memorandum that includes the list of terms and conditions describing the pricing, structure, collateral, covenant package, and other terms of credit. Credit and security agreements detail the loan's final terms (Standard and Poor's 2011).

We obtain loan data from Dealscan, which collects loan information directly from borrowers and lenders. Dealscan also collects information from SEC fillings such as10Ks, 10-Qs, 8-Ks, and registration statements. This dataset allows us to compare loans disclosed contemporaneously in Form 8-K to those disclosed only in delayed annual or quarterly reports (10-K or $10-\mathrm{Q}$, respectively) or not at all.

\section{Hypotheses, research design and sample}

\subsection{Hypothesis development}

We test whether firms exhibit a reluctance to disclose loans with high spreads, and use a model in Appendix 1 to formalize our hypotheses. Loan spreads can convey banks' private information on borrowers' future earnings and R\&D (Yu 2013; Plumlee et al. 2015). Because of this, firms may wish to avoid drawing attention to high-spread loans in order to reduce the stock price impact of both the negative information signaled by the high spreads and the effects of higher interest payments. This leads to our first hypothesis:

H1 The probability of withholding loan disclosure is increasing in the loan spread.

While high spreads increase the benefit of nondisclosure, firms must balance this against the costs of nondisclosure. In addition to the regulatory costs that we examine in Section 6, we expect that nondisclosure varies with other related costs. Prior literature documents that auditor reputation is positively correlated with $8-\mathrm{K}$ disclosure quality (Schwartz and Soo 1996), suggesting that high-quality auditors increase the overall cost of noncompliance. In addition, industry competition can increase the cost of disclosing proprietary information and reduce a firm's incentive to disclose (Verrecchia and Weber 2006; Verrecchia 1990). This leads to our next hypotheses:

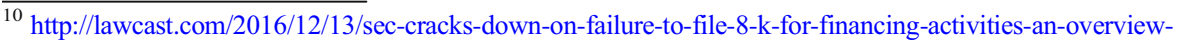
of-form-8-k/
} 
$\mathrm{H} 2 \mathrm{a}$ The incentive to withhold loan disclosure is stronger for firms with less reputable auditors.

$\mathrm{H} 2 \mathrm{~b}$ The incentive to withhold loan disclosure is stronger for firms in highly competitive industries.

When firms fail to disclose a loan, investors can still obtain somewhat noisy information about the presence of the loan via subsequent financial statements. New borrowings increase interest expense, debt balances, and cash inflows from financing. If investors believe that a firm obtained a loan but failed to disclose it, they may react skeptically because the firm likely would have disclosed the loan had it reflected well on the firm (e.g., Dye 1985; Jung and Kwon 1988). As a result, a firm benefits less from not disclosing when investors are more likely to otherwise infer that it borrowed. We conjecture two situations where this might occur. First, investors may expect borrowings to accompany acquisitions. Second, equity analysts interpret and convey information to investors (e.g., Kross et al. 1990; Huang et al. 2018), which may reveal evidence of undisclosed borrowings. This leads to our next hypotheses:

H3a Firms are less likely to withhold loan disclosure when they engage in acquisitions.

H3b Firms are less likely to withhold loan disclosure when they are followed by more equity analysts.

We further predict that firms benefit less from failing to disclose loans when investors pay more attention to their financial statements. Similar to the effect that analysts have on potentially revealing undisclosed loans, investors themselves may identify evidence of undisclosed loans when they more thoroughly read financial statements. In addition to direct measures of attention, the model in Appendix 1 shows that an increase in volatility will increase investor reaction to a firm's news and decrease the benefit of hiding loans. This is analogous to Jung and Kwon's (1988) prediction that more volatile cash flows lead to more voluntary disclosure. Consistent with this notion, Chamberlain et al. (2005) provide evidence that investors pay more attention to the financial statements of firms with high stock return volatility.

This leads to our fourth hypotheses:

H4a Firms with high investor attention are less likely to withhold loan disclosure.

H4b Firms with highly volatile company value are less likely to withhold loan disclosure.

Financial covenants contain proprietary information. Disclosing them may be costly for the borrowers. Prior literature shows that loans with tight covenants are associated with a higher frequency of technical default and lower future investment spending (Chava and Roberts 2008; Demiroglu and James 2010), and with reduced (Saavedra 2018). Disclosing these loans may have negative capital market consequences. Thus, we predict that firms strategically withhold disclosures on loans with stringent covenants.

H5 Firms are more likely to withhold disclosure of loans with stringent covenants. 


\subsection{Test specification}

To investigate the determinants of the nondisclosure of loans, we employ the following regression framework for firm $i$, loan facility $\ell$, and year $t^{11}$ :

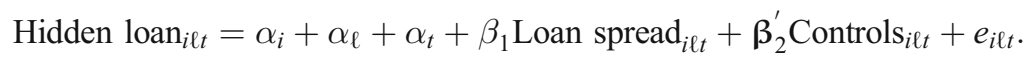

The outcome variable Hidden Loan is a dummy variable that equals one if the credit facility is not disclosed in an $8-\mathrm{K}$ around the time that the loan has been issued based on Dealscan. ${ }^{12}$ Regression (1) includes firm fixed effects $\left(\alpha_{i}\right)$ to control for borrowerspecific time-invariant omitted variables, and year fixed effects $\left(\alpha_{t}\right)$. The regression also includes a set $\alpha_{\ell}$ of loan-type fixed effects that account for the types of facilities that are part of the loan. ${ }^{13}$ The main explanatory variable of interest is Loan Spread, which is the all-in spread drawn as provided in the Dealscan database. All-in spread drawn is defined as the amount the borrower pays in basis points over LIBOR or the LIBOR equivalent for each dollar drawn down (e.g., Graham et al. 2008). ${ }^{14}$ This measure adds the borrowing spread of the loan over LIBOR to any annual fee paid to lenders. We also include a set of controls that are described in more detail below. We winsorize all continuous variables at the $0.5 \%$ and $99.5 \%$ levels to limit the influence of outliers. ${ }^{15}$ Finally, we cluster standard errors at the package level. Our prediction is that $\beta_{1}>0$, consistent with firms being more likely to hide their high spread loans.

The specification includes controls for a number of facility and firm level characteristics that might influence the nondisclosure of potentially material information. These variables include the following:

\subsubsection{Loan-level controls}

1. Log Loan Amount is the logarithm of the loan facility amount. We hypothesize that firms are less likely to hide larger loans, because it is more difficult for firms to hide large loans in the financial statements.

2. Log Maturity is maturity of the loan measured in months. We do not have an ex ante prediction on the coefficient.

\footnotetext{
${ }^{11}$ Consistent with the suggestion in Angrist and Pischke (2009), throughout the paper we use a linear probability model to allow for the use of fixed effects and to simplify the interpretation of the coefficients.

${ }^{12}$ We look at a 10-day window around the Dealscan issuance date. We discuss this in more detail in the sample selection section.

${ }^{13}$ Loan type is given by the "Loan Type" variable in the Dealscan, which includes 364-Day Facility, Acquisition Facility, Bridge Loan, Delay Draw Term Loan, Demand Loan, Mortgage Facility, Revolver, Term Loan (from term loan A to term loan I), and other loans.

${ }^{14}$ For loans not based on LIBOR, DealScan converts the spread into LIBOR terms by adding or subtracting a differential that is adjusted periodically.

${ }^{15}$ Winsorizing at the 1 st and 99 th percentiles does not affect any of our results.
} 


\subsubsection{Firm-level controls}

3. Log Assets is measured at the quarter end before the loan starting date. On the one hand, Carter and Soo (1999) find that large firms better comply with Form 8-K requirements under the pre-2004 rules. On the other hand, the model in Appendix 1 predicts that the easier it is for firms to "bury" loans in their financial statements, the more likely it is that the firms will hide loans. Because larger firms tend to have more complex financial statements, we hypothesize that they are more likely to hide loans.

4. Equity Issue is a dummy variable that equals one if the loan is made in the month of or in the month before an equity offering. ${ }^{16}$ We hypothesize that firms are less likely to hide loans in years in which they issue stock. This is based on evidence in Lang and Lundholm (1993), Frankel et al. (1995), and Sengupta (1998) that firms increase disclosure or provide higher quality disclosures in anticipation of upcoming public equity offerings.

5. ROA is defined as net income divided by total assets. Lang and Lundholm (1993) argue that it is not clear how firm performance affects the decision to disclose. Profitable firms may choose not to disclose because disclosure encourages entrance and competition. Alternatively, if there are costs to disclosure, then more profitable firms have stronger incentives to disclose and reduce costs that result from adverse selection. Thus, it is not clear whether profitability is positively or negatively associated with the extent of disclosure.

6. Book Leverage is the ratio of total debt to total assets, measured at the quarter end before the loan starting date.

7. Loss is a dummy variable that equals one if net income in the quarter before the loan starting date is negative.

8. Z-Score is the Altman (1968) Z-score measured at the quarter end before the loan starting date.

Book leverage, Loss, and Z-Score might affect firms' disclosure behavior, as investors may expect high leverage firms, loss firms, and distressed firms to have a higher prior probability of borrowing.

\subsection{Sample selection}

Our base sample consists of all Dealscan facilities that can be linked to Compustat Quarterly Fundamental Data using the Dealscan-Compustat Linking Table for all US companies. Our sample begins in 2005 because the SEC amended the 8-K disclosure requirements in August 2004. Under the new rule, firms have to disclose material loan contracts in Item 1.01 or Item 2.03 within four business days. ${ }^{17}$ Our sample ends in 2017, as the Dealscan-Compustat Linking Table ends in 2017. We remove credit facilities that cannot be matched to CRSP monthly returns and firm-years with no

\footnotetext{
${ }^{16}$ We search all of the 424B fillings in the EDGAR. We identify a 424B filing as an equity offering if it includes the pattern "offering $[\mathrm{X}]$ shares of the common stock," or variations including stock, ordinary stock, ordinary share, and preferred stock.

${ }^{17}$ See https://www.sec.gov/rules/final/33-8400.htm for the new disclosure rule. Before the new rule, there was no specific item number for loan contracts, and the deadline for filing an $8-\mathrm{K}$ was 15 calendar days.
} 
public disclosure on EDGAR to make sure that firms in our sample fall under the SEC mandate. $^{18}$

We eliminate loans with a missing interest rate, loan amount, or maturity. We exclude credit facilities that were issued 10 or fewer days before $10-\mathrm{K}$ or $10-\mathrm{Q}$ filing dates because companies may directly attach the loan contract to the $10-\mathrm{K}$ or $10-\mathrm{Q}$ instead of filing a separate $8-\mathrm{K}$ when the loan is signed close to the $10-\mathrm{K}$ or $10-\mathrm{Q}$ release date. In these cases, it is difficult to tell whether the manager is intentionally trying to obfuscate the loan information by bundling it with the $10-\mathrm{K}$ or $10-\mathrm{Q}$ or simply does not feel the need to issue an additional $8-\mathrm{K}$ because the information is in the $10-\mathrm{K}$ or $10-\mathrm{Q} .{ }^{19}$ We exclude firms that never make $8-\mathrm{K}$ loan disclosures because all of our analysis focuses on within-firm variation.

Lastly, we review cases where the Dealscan-Compustat linking table assigns one GVKEY identifier to multiple Dealscan borrower IDs. This typically occurs when the borrower is a subsidiary of the public parent. However, in a few cases where a company obtains a loan prior to being acquired by a public parent, the Linking Table misattributes the subsidiary's loan to the public parent. For example, AmerisourceBergen acquired PharMEDium Healthcare in 2015, but the Linking Table misattributes a loan by PharMEDium in 2007 to AmerisourceBergen (Dealscan facilityid 224,356). ${ }^{20}$ Although such misattributions are uncommon, they may bias our analysis in favor of finding results, as the loans taken by these borrowers before being acquired by the public parent often have higher spreads. We manually review the sample and drop 470 observations due to such misattributions. Our final sample consists of 13,628 credit facilities corresponding to 2766 unique firms. Table 1 summarizes our sample selection process.

For each of these 13,628 credit facilities, we search all 8 -K filings in a 10-day window around the facility starting date (from two calendar days before to seven calendar days after the facility start date). Given that the SEC requires firms to release the 8-K within four business days after the material event, we expect that the 10-day window around the facility starting date will capture most of the loan disclosures. We identify an $8-\mathrm{K}$ as a loan disclosure if the $8-\mathrm{K}$ file mentions keywords such as "credit agreement" or its variations. ${ }^{21}$

Table 1 also breaks down our sample based on whether and how loans are disclosed. Among the 13,628 credit facilities in our sample, 11,136 (82\%) are disclosed in an 8-K around the time the loan was issued. The disclosure rate is similar to Saavedra (2019b), who finds a corresponding contract on EDGAR for $86 \%$ of the Dealscan loans in his sample. As a robustness check, we expand the 10-day matching window by two more days (from two calendar days before facility start to nine calendar days after, instead of seven). Expanding the matching window only increases the number of matched loans

\footnotetext{
${ }^{18}$ Most of these loans cannot be matched to an 8-K because they are issued before the firm's IPO or after the firm is no longer publicly traded.

19 As a robustness check, in untabulated tests we include these loans around 10-K or 10-Q filing dates, and our main results are unchanged.

${ }^{20} \mathrm{https}$ //www.reuters.com/article/us-pharmedium-m-a-amerisourcebergn/amerisourcebergen-to-buypharmedium-for-2-58-billion-idUSKCN0S019P20151006.

${ }^{21}$ The full list of variations is as follows: credit agreement, loan and security agreement, credit and security agreement, loan agreement, loan modification agreement, loan modification/renewal agreement, loan facility agreement and guaranty, credit line agreement, revolving credit facility, credit facility, loan facility, and off balance sheet facility.
} 
Table 1 Sample construction

$\begin{array}{ll}\text { Sample construction } & \text { Obs } \\ \text { Dealscan facilities matched with Compustat } & 27,408 \\ \text { Less: } & \\ \text { Missing CRSP monthly return or do not have any public disclosure in EDGAR in the year } & (7,753) \\ \text { Missing loan spread } & (1,957) \\ \text { Missing loan amount or maturity } & (141) \\ \text { Facilities within 10 days before 10-K/10-Q } & (2,397) \\ \text { Firms that never disclose loans in 8-K } & (1,062) \\ \text { Manually checked wrong loans } & (470) \\ \text { Total number of Facilities } & 13,628 \\ \text { Detailed breakdown } & \\ \text { Disclosed loans } & \\ \text { Correctly classified } & 10,868 \\ \text { Misclassified } & 268 \\ \text { Total number of disclosed loans } & 11,136 \\ \text { Undisclosed (hidden) loans } & \\ \text { In 10-K/10-Q } & 1,881 \\ \text { Not in 10-K/10-Q } & 611 \\ \text { Total number of undisclosed (hidden) loans } & 2,492\end{array}$

This table details the derivation of our final sample

by $0.71 \%$ (97 new matched loans), suggesting that the 10-day window used in the main analysis captures most of the disclosed loans in the 8-K. Incorporating these newly matched loans does not affect any of our results. On the other hand, expanding the matching window beyond the 8-K disclosure deadline (four business days) increases the risk of misattribution; thus, we use the 10-day window for all of our analysis.

Most of the disclosed loans are correctly labeled in 8-Ks as item 1.01 (material contract) or 2.03 (off-balance sheet facility). However, 2.4\% of the disclosed loans are misclassified as item 8.01 (other items), 7.01 (RegFD disclosure) or 2.01 (asset acquisition or disposition). With respect to the 2492 undisclosed credit facilities (18\% of the sample), we check whether they are mentioned in the subsequent 10-Ks or 10-Qs. ${ }^{22}$ Approximately $75 \%$ of the undisclosed loans are discussed in subsequent $10-$ Ks or 10 -Qs. The remaining $25 \%$ are never disclosed. Appendix 3 provides examples of two undisclosed loans and one misclassified loan.

\footnotetext{
${ }^{22}$ For each undisclosed facility, we use a Python program to check the subsequent two 10-Qs (or one 10-Q and one 10-K if the loan is signed in Q3 or Q4). We classify a previously undisclosed loan as mentioned in the 10-Q or 10-K if one of the three following conditions are met: (1) the facility starting date is mentioned within 25 words of the keyword "credit agreement" or its variations, (2) the facility starting month is mentioned within 25 words of the keyword "credit agreement" or its variations, (3) the loan amount is mentioned within 25 words of the keyword "credit agreement" or its variations. The list of variations of "credit agreement" can be found in footnote 21. In addition, we also use "term loan", "bank loan", "credit line" and "bank debt" as the keywords, because managers sometimes use these terms when discussing liquidity in the 10-K or 10-Q (e.g., "the amounts outstanding on the term loan and mortgage were XXX").
} 


\section{Empirical results}

\subsection{Descriptive statistics}

Table 2 Panel A reports summary statistics for our sample. The average (median) loan amount is $\$ 535 \mathrm{M}(\$ 250 \mathrm{M})$, and the average (median) loan spread is $2.1 \%(1.75 \%)$. Compared to the full set of firms in Compustat in the same period, the firms in our sample are larger and have higher Z-Scores. ${ }^{23}$ The average (median) loan-to-asset ratio is $19.2 \%(12.2 \%)$, suggesting that loan issuances are material events. Figure 1 shows that the loan-to-asset ratio decreases with firm size. For example, the median loan is $3.2 \%$ of assets for firms in the largest decile of total assets, $6.3 \%$ for the second-largest decile, and $7.7 \%$ for the third largest decile. For each of the smallest five size deciles, roughly $90 \%$ of loans exceed $5 \%$ of assets. In the largest size decile, roughly $75 \%$ of loans fall below $5 \%$ of assets. Later in the paper, we examine whether firms exploit the ambiguous definition of materiality as roughly proxied by the loan-to-asset ratio.

Approximately $17.1 \%$ of loans in our sample are used for asset acquisitions. ${ }^{24}$ Table 2 Panel B reports the distribution of loans by loan purpose for disclosed and hidden loans. The top three reasons for taking the loan are "corporate purpose," "working capital," and "takeover." The distribution by loan purpose does not differ between disclosed loans and undisclosed loans.

Table 2 Panel $\mathrm{C}$ compares the characteristics of hidden and disclosed loans. Consistent with H1, hidden loans have higher loan spreads than disclosed loans (2.196 vs. 2.117). Hidden loans are larger, on average, than disclosed loans ( $\$ 573 \mathrm{M}$ vs. $\$ 526 \mathrm{M})$; however, they are smaller, on average, relative to assets (15.6\% vs. $20.0 \%$ ). This implies that larger companies more often fail to file Form $8-\mathrm{K}$ for credit facilities. Panel $\mathrm{C}$ also shows that hidden loans have a shorter maturity, on average, than disclosed loans (51.5 months vs. 52.6 months).

\subsection{Main results}

Table 3 Panel A provides the full-sample results from estimating Eq. 1 using different specifications. Columns (1)-(3) present regression results where the dependent variable Hidden Loan equals 1 for loans not disclosed in an $8-\mathrm{K}$ and 0 otherwise. Columns (4)-(6) present regression results where the dependent variable Hidden Loan (Ordered) equals 2 if the loan is disclosed in neither an $8-\mathrm{K}$ nor a $10-\mathrm{K} / \mathrm{Q}$, equals 1 if the loan is not disclosed in an $8-\mathrm{K}$ but is disclosed in a $10-\mathrm{K} / \mathrm{Q}$, and equals 0 if the loan is disclosed in an 8-K.

The coefficient on Loan Spread is positive and statistically significant at the $1 \%$ level across all specifications in Table 3 Panel A. In column 3, our most robust specification, the coefficient on Loan Spread is 0.0329 , suggesting that a one standard deviation increase in loan spreads increases the probability of hiding a loan by $4.5 \% .^{25}$

\footnotetext{
${ }^{23}$ The median Log Asset and Z-score for all firms in Compustat from 2005 to 2017 are 5.72 and 1.2, respectively. In our sample, the median Log Asset and Z-score are 7.7 and 1.47, respectively.

${ }^{24}$ We define "asset acquisitions" as loans with a stated purpose of takeover, merger, acquisition, LBO, equipment purchases, or capital expenditure.

${ }^{25}$ The $4.5 \%$ figure equals the 0.0329 coefficient multiplied by the 1.374 standard deviation of spread (Table 2).
} 
Table 2 Summary statistics

Panel A: Descriptive statistics

\begin{tabular}{|c|c|c|c|c|c|c|c|c|}
\hline & $\mathrm{N}$ & Mean & SD & p1 & $\mathrm{p} 25$ & $\mathrm{p} 50$ & p75 & p99 \\
\hline Hidden Loan & 13,628 & 0.183 & 0.387 & 0.000 & 0.000 & 0.000 & 0.000 & 1.000 \\
\hline Hidden Loan (Ordered) & 13,628 & 0.228 & 0.515 & 0.000 & 0.000 & 0.000 & 0.000 & 2.000 \\
\hline Misclassified Loan & 13,628 & 0.020 & 0.139 & 0.000 & 0.000 & 0.000 & 0.000 & 1.000 \\
\hline Loan Spread & 13,628 & 2.132 & 1.374 & 0.200 & 1.250 & 1.750 & 2.750 & 7.500 \\
\hline Loan Amount (\$M) & 13,628 & 535.0 & 837.6 & 5.0 & 100.0 & 250.0 & 600.0 & 4500.0 \\
\hline Maturity & 13,628 & 52.429 & 18.503 & 6.00 & 42.00 & 60.00 & 60.00 & 85.00 \\
\hline Loan to Asset & 13,600 & 0.192 & 0.219 & 0.002 & 0.055 & 0.122 & 0.249 & 1.131 \\
\hline Log Asset & 13,600 & 7.699 & 1.647 & 4.129 & 6.564 & 7.652 & 8.745 & 12.004 \\
\hline Equity Issue & 13,628 & 0.035 & 0.183 & 0.000 & 0.000 & 0.000 & 0.000 & 1.000 \\
\hline $\mathrm{ROA}$ & 13,587 & 0.009 & 0.028 & -0.123 & 0.002 & 0.010 & 0.019 & 0.082 \\
\hline Book Leverage & 13,600 & 0.322 & 0.219 & 0.000 & 0.157 & 0.302 & 0.458 & 0.960 \\
\hline Negative NI & 13,606 & 0.184 & 0.388 & 0.000 & 0.000 & 0.000 & 0.000 & 1.000 \\
\hline Z_Score & 13,241 & 2.128 & 2.810 & -2.000 & 0.709 & 1.471 & 2.625 & 16.105 \\
\hline Acquire Asset & 13,628 & 0.171 & 0.376 & 0.000 & 0.000 & 0.000 & 0.000 & 1.000 \\
\hline \# of Analysts & 13,628 & 10.387 & 9.247 & 0.000 & 3.000 & 8.000 & 16.000 & 40.000 \\
\hline Volatility & 12,926 & 0.094 & 0.062 & 0.021 & 0.054 & 0.079 & 0.116 & 0.357 \\
\hline EDGAR Downloads & 13,155 & 270.90 & 292.95 & 2.000 & 89.000 & 190.50 & 345.00 & 1521.0 \\
\hline Big 4 & 13,628 & 0.069 & 0.073 & 0.011 & 0.029 & 0.043 & 0.080 & 0.386 \\
\hline Herfindal Index & 13,361 & 0.889 & 0.314 & 0.000 & 1.000 & 1.000 & 1.000 & 1.000 \\
\hline
\end{tabular}

Hidden

\section{Disclosed}

$\begin{array}{llllll}\text { Loan Purpose } & \mathrm{N} & \text { Percent } & \text { Loan Purpose } & \mathrm{N} & \text { Percent } \\ \text { Corp. purposes } & 1,585 & 63.55 & \text { Corp. purposes } & 6,365 & 57.17 \\ \text { Work. cap. } & 240 & 9.62 & \text { Work. cap. } & 1,963 & 17.63 \\ \text { Takeover } & 155 & 6.21 & \text { Takeover } & 1,163 & 10.45 \\ \text { Acquis. line } & 123 & 4.93 & \text { Acquis. line } & 592 & 5.32 \\ \text { LBO } & 118 & 4.73 & \text { Debt Repay. } & 397 & 3.57\end{array}$

Panel C. Comparison of loan characteristics

\begin{tabular}{lllllllll} 
& \multicolumn{7}{c}{ Hidden } & \multicolumn{7}{c}{ Disclosed } \\
& $\mathrm{N}$ & Mean & $\mathrm{SD}$ & $\mathrm{N}$ & Mean & SD & Difference & t-statistic \\
Loan Spread & 2,492 & 2.196 & 1.530 & 11,136 & 2.117 & 1.336 & 0.079 & $2.61^{* * * *}$ \\
Loan Amount $(\$ \mathrm{M})$ & 2,492 & 576.479 & 952.111 & 11,136 & 525.665 & 809.527 & 50.815 & $2.74^{* * *}$ \\
Maturity & 2,492 & 51.481 & 21.023 & 11,136 & 52.641 & 17.884 & -1.160 & $-2.83^{* * * *}$ \\
Loan to Asset & 2,483 & 0.156 & 0.223 & 11,117 & 0.200 & 0.217 & -0.044 & $-9.02^{* * * *}$ \\
\hline
\end{tabular}

Panel A reports the summary statistics of Dealscan loans and firm characteristics in our sample. All continuous variables are winsorized at the $0.5 \%-99.5 \%$ level. All variables are defined in the Appendix B. Panel B reports the distribution by loan purpose. Panel $\mathrm{C}$ compares the characteristics between disclosed and undisclosed loans 
Given that $18.3 \%$ of loans in our sample are hidden, this coefficient is economically significant, as it represents a $25 \%$ increase from the baseline. Our results are consistent with our prediction that the probability of withholding loan disclosure is increasing in the loan spread (H1). We characterize this as a within-firm comparison because our use of firm fixed effects controls for firms' typical spreads.

To further strengthen our inferences, the specifications in columns (4)-(6) take advantage of the fact that firms sometimes hide loans until a subsequent $10-\mathrm{K} / \mathrm{Q}$ release, while at other times they never disclose the loan. The dependent variable Hidden Loan (Ordered) corresponds to increasingly opaque disclosures as explained above. We expect stronger results for firms with more opaque disclosure. Consistent with our predictions, columns (4)-(6) show that higher loan spreads are associated with increasingly opaque disclosures.

With respect to the control variables, we find evidence that the loan amount is negatively correlated with the probability of withholding, as it is more difficult for firms to hide larger loans. Consistent with Verrecchia and Weber (2006), we find that firms are less likely to hide loans before equity issuances and when they experience losses. Lastly, we find that larger firms are more likely to hide loans.

To mitigate concerns that our results are driven by immaterial loans, Table 3 Panel B columns (1) and (4) present the same regression specifications for the subsample that excludes loans with a value of less than 5\% of total assets. The downside of this restriction is that it excludes many loans from large companies because the size of individual loans does not scale with company size as shown in Fig. 1. Larger companies hide loans more frequently, as can be inferred from the positive coefficient for $\log$ Assets in Panel A. Larger companies arguably face a lower cost of hiding loans because their other financial activities can obscure the impact of new loans. Larger companies can also more easily claim that loans are immaterial, because they typically borrow in

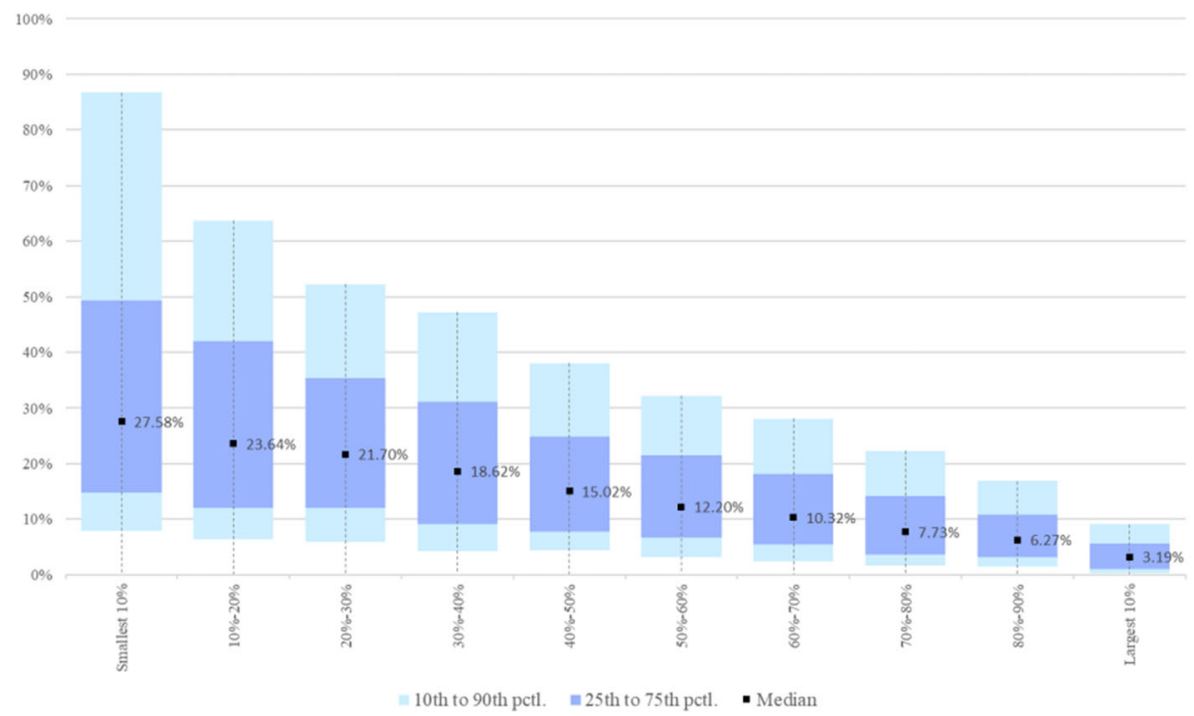

Fig. 1 Loan size by decile of total assets. This figure illustrates the distribution of the loan-to-asset ratio by firm size decile. The squares indicate the median; the dark-shaded area is the 25th-to-75th percentile range; and the light-shaded area is the 10th-to-90th percentile range 
Table 3 Main results - loan spread and hidden loans

Panel A: Full sample

Hidden Loan

(1)

Loan Spread

Log Loan Amount

Log Maturity

Log Asset

Equity Issue

ROA

Book Leverage

Loss

Z-Score

Observations

R-squared

Year FE

Borrower FE

Loan Type FE
(2)

$0.0415^{* * * *}$
$(8.45)$

(6.59)

$-0.0588^{* * *}$

$(-12.70)$

$-0.00993$

$(-0.78)$

(3) $0.0329^{\text {**** }}$

(6.73)

$-0.0614^{* * *}$

$(-12.87)$

$-0.00971$

$(-0.77)$

$0.0455^{* * *}$

(3.39)

$-0.0556^{*}$

$(-1.81)$

0.0241

(0.10)

0.0758

(1.39)

$-0.0384^{* * *}$

$(-2.19)$

0.00541

(1.59)

$1.035^{* * *}$

(6.77)

13,230

0.374

YES

YES

YES
Hidden Loan (Ordered)

(4)

(5)

(6)

$0.0688^{* * *} \quad 0.0550^{* * *} \quad 0.0582^{* * *}$

$\begin{array}{lll}(9.58) & (8.14) \quad(8.33)\end{array}$

$-0.0786^{\text {*** }}-0.0809^{\text {**** }}$

$(-11.92) \quad(-11.83)$

$-0.00533 \quad-0.00533$

$(-0.32)$

$(-0.32)$

$0.0480^{* * *}$

(2.80)

$-0.0722^{*}$

$(-1.82)$

0.115

$(0.35)$

0.0867

(1.24)

$-0.0538^{* * *}$

$(-2.40)$

0.00681

(1.61)

$1.351^{* * *}$

(7.13)

13,230

0.411

YES

YES

YES

Panel B: Subsample analysis

Hidden Loan

$\begin{array}{lllllll}\text { VARIABLES } & (1) & (2) & (3) & (4) & (5) & (6) \\ \text { Loan-to-asset } & \geq 5 \% & <5 \% & <2.5 \% & \geq 5 \% & <5 \% & <2.5 \% \\ \text { Loan Spread } & 0.0212^{* * *} & 0.0445^{* * *} & 0.0703^{* * *} & 0.0359^{* * *} & 0.0987^{* * *} & 0.122^{* * *} \\ & (3.81) & (3.28) & (3.53) & (4.73) & (5.34) & (4.37) \\ \text { Log Loan Amount } & -0.0230^{* * *} & -0.0659^{* * *} & -0.0366^{*} & -0.0218^{* *} & -0.0910^{* * * *} & -0.0535 \\ & (-3.25) & (-5.12) & (-1.92) & (-2.24) & (-4.47) & (-1.63) \\ \text { Log Maturity } & -0.0176 & 0.00316 & -0.0431 & -0.0123 & -0.00328 & -0.0537 \\ & (-1.12) & (0.12) & (-1.00) & (-0.62) & (-0.08) & (-0.82) \\ \text { Log Asset } & 0.0205 & 0.00309 & -0.0948 & 0.0115 & 0.0146 & -0.109 \\ & (1.41) & (0.07) & (-1.42) & (0.63) & (0.25) & (-1.03) \\ \text { Equity Issue } & -0.0448 & -0.0848 & -0.0268 & -0.0608 & -0.0836 & 0.0317 \\ & (-1.41) & (-0.99) & (-0.24) & (-1.48) & (-0.72) & (0.18)\end{array}$


Table 3 (continued)

Panel A: Full sample

\begin{tabular}{|c|c|c|c|c|c|c|}
\hline & \multicolumn{3}{|c|}{ Hidden Loan } & \multicolumn{3}{|c|}{ Hidden Loan (Ordered) } \\
\hline & (1) & (2) & (3) & (4) & $(5)$ & (6) \\
\hline \multirow[t]{2}{*}{$\mathrm{ROA}$} & -0.208 & 0.289 & 0.932 & -0.164 & 0.0202 & -0.800 \\
\hline & $(-0.80)$ & $(0.44)$ & $(0.77)$ & $(-0.52)$ & $(0.02)$ & $(-0.33)$ \\
\hline \multirow[t]{2}{*}{ Book Leverage } & 0.0695 & 0.171 & 0.482 & 0.0996 & 0.103 & 0.225 \\
\hline & $(1.25)$ & $(0.91)$ & $(1.63)$ & $(1.42)$ & $(0.39)$ & $(0.52)$ \\
\hline \multirow[t]{2}{*}{ Loss } & $-0.0345^{*}$ & -0.0551 & -0.0802 & $-0.0512^{* *}$ & -0.0698 & -0.108 \\
\hline & $(-1.85)$ & $(-1.22)$ & $(-1.12)$ & $(-2.24)$ & $(-1.12)$ & $(-0.99)$ \\
\hline \multirow[t]{2}{*}{ Z-Score } & 0.00402 & -0.0107 & 0.0297 & 0.00512 & -0.00801 & 0.0455 \\
\hline & $(1.12)$ & $(-0.74)$ & $(0.64)$ & $(1.17)$ & $(-0.40)$ & $(0.64)$ \\
\hline \multirow[t]{2}{*}{ Constant } & $0.495^{* *}$ & $2.356^{* * *}$ & $2.555^{* * * *}$ & $0.494^{* *}$ & $2.824^{* * *}$ & $3.181^{* * * *}$ \\
\hline & $(2.30)$ & $(5.11)$ & $(3.56)$ & $(1.98)$ & $(4.51)$ & $(3.02)$ \\
\hline Observations & 10,166 & 3,064 & 1,475 & 10,166 & 3,064 & 1,475 \\
\hline R-squared & 0.366 & 0.570 & 0.673 & 0.416 & 0.584 & 0.670 \\
\hline Year FE & YES & YES & YES & YES & YES & YES \\
\hline Borrower FE & YES & YES & YES & YES & YES & YES \\
\hline Loan Type FE & YES & YES & YES & YES & YES & YES \\
\hline
\end{tabular}

Panel C: Loan spread and hidden loans - With Borrower $\times$ Loan type fixed effects

Hidden Loan

(1)

Log Loan Amount

Log Maturity

Log Asset

Equity Issue

ROA

Book Leverage

Loss

Z-Score

Constant

Observations $0.0488^{* * *}$ (5.86)

(2) $0.0300^{* * *} \quad 0.0322^{* * *}$ (3.71) $-0.0683^{* * *}$ $(-10.28)$ $-0.0326^{*}$ $(-1.65)$ (3.91) $-0.0721^{\text {*** }}$ $(-10.51)$ $-0.0287$ $(-1.46)$ $0.0534^{* * * *}$ (3.32) $-0.0622^{*}$ $(-1.67)$ $-0.225$ $(-0.78)$ 0.0865 (1.31) $-0.0485^{\text {** }}$ $(-2.33)$ $0.00730^{*}$ (1.82) $0.134^{* * *} \quad 1.582^{* * *} \quad 1.209^{* * *}$ (5.63) (11.27) 13,628 (7.11) Hidden Loan (Ordered)

(4) (5) (6) $0.0818^{* * *} \quad 0.0574^{* * *} \quad 0.0612^{* * *}$

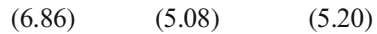
$-0.0895^{* * *}-0.0937^{* * *}$ $(-9.62) \quad(-9.64)$ $-0.0189 \quad-0.0147$ $(-0.73) \quad(-0.57)$ $0.0558^{* * *}$ (2.80) $-0.0782$ $(-1.63)$ $-0.282$ $(-0.78)$ 0.0985 (1.19) $-0.0656^{\text {*** }}$ $(-2.52)$ $0.00921^{*}$ (1.86) $1.526^{* * * *}$ $0.110^{* * *}$ $1.915^{* * *}$ (6.85)

$(3.58) \quad(9.99) \quad(6.85)$
13.628


Table 3 (continued)

Panel A: Full sample

\begin{tabular}{|c|c|c|c|c|c|c|}
\hline & \multicolumn{3}{|c|}{ Hidden Loan } & \multicolumn{3}{|c|}{ Hidden Loan (Ordered) } \\
\hline & _(1) & (2) & (3) & (4) & (5) & (6) \\
\hline R-squared & 0.515 & 0.527 & 0.534 & 0.570 & 0.581 & 0.587 \\
\hline Year FE & YES & YES & YES & YES & YES & YES \\
\hline Borrower-Loan type FE & YES & YES & YES & YES & YES & YES \\
\hline
\end{tabular}

This table reports the regression results of Hidden Loan on loan spread. Each observation is a loan facility. Panel A presents regression results for our full sample. Panel B presents results using the subsample of loans with loan-to-asset ratio greater than $5 \%$, lower than $5 \%$, or lower than $2.5 \%$. Panel C presents results where we include Firm $\times$ Loan Type fixed effects. In columns (1) - (3), the dependent variable Hidden Loan equals 1 if the loan is not disclosed in an 8-K and 0 otherwise. In columns (4) - (6), the dependent variable Hidden Loan (Ordered) equals 2 if the loan is disclosed in neither an $8-\mathrm{K}$ nor a 10-K/Q, 1 if the loan is not disclosed in an 8$\mathrm{K}$ but is discussed in a subsequent $10-\mathrm{K} / \mathrm{Q}$, and 0 if the loan is disclosed in an $8-\mathrm{K}$. Appendix $\mathrm{B}$ defines the independent variables. Robust standard errors are clustered at package level. Each coefficient's t-statistic appears directly below the coefficient estimate. ${ }^{* * *},{ }^{* *}$, and ${ }^{*}$ denote statistical significance at the $1 \%, 5 \%$, and $10 \%$ levels, respectively

increments that are small relative to company size. After eliminating loans of less than $5 \%$ of assets in Table 3 Panel B columns (1) and (4), we obtain results that are slightly weaker than those in Panel A but still significant at $1 \%$.

In columns (2), (3), (5), and (6), we run the same regression specification, only for the subsamples of loans with less than $5 \%$ and $2.5 \%$ of assets, respectively. As shown in Fig. 1, large firms issue most of these loans. The coefficients on loan spread in these two subsamples are statistically larger than in the greater-than-5\% subsample. ${ }^{26}$ This result is consistent with firms exploiting the "blindspots" inherent in rule-of-thumb materiality rules such as $5 \%$ of earnings or assets (Georgiev 2017), as they selectively disclose loans with lower spreads but hide loans with higher spreads when materiality constraints are less binding. Overall, the evidence suggests that firms appear to exploit the ambiguous definition of materiality.

Finally, in Table 3 Panel C, we present similar results using borrower-loan type fixed effects. This fixed effects structure further strengthens the case that our results are not driven by a specific loan type. It also alleviates the concern that our main results may reflect firms that do not disclose revolvers from which they have not yet drawn. However, per discussions with SEC personnel, firms are required to disclose the revolver loan facility even if they have not yet drawn from it. To further address this concern, we conduct an untabulated test that excludes revolvers and find similar results.

\subsection{Misclassified loans}

As opposed to failing to file a Form 8-K, firms can obscure loan information by misclassifying loan disclosures in their $8-\mathrm{Ks}$. Firms are required to disclose

\footnotetext{
${ }^{26}$ The difference between columns (1) and (2) is significant at the $10 \%$ level, and the differences between columns (1) and (3), (4) and (5), and (4) and (6) are all significant at 5\%.
} 
loan information under items number 1.01 (material contract) or 2.03 (off-balance sheet facility) following the SEC's new disclosure requirements for Form 8-K, which became effective on August 23, 2004 (see, e.g., Lerman and Livnat 2010). However, firms can make loans more difficult to find or less salient by disclosing them under a different category. For example, Bird et al. (2018) document that firms strategically misclassify items such as material contracts (item 1.01), director turnover (item 5.02), and delisting (item 3.01) into other events (item 8.01), and they find lower search traffic and market reactions to the information in misclassified disclosures.

To test for this, we run regression (1) using the dependent variable Misclassified, which is an indicator variable that equals 1 if the credit facility is disclosed in an $8-\mathrm{K}$ under an item number other than 1.01 (material contract) or 2.03 (off-balance sheet facility), and zero if it is disclosed under item 1.01 or 2.03. This test excludes all hidden loans because they do not have an $8-\mathrm{K}$ disclosure. Table 4 shows our results. The evidence is consistent with the probability of misclassifying loans increasing in loan spread. We find no relation between loan size and disclosure misclassification, as firms appear to misclassify both large and small loans. Overall, this more nuanced test provides further evidence that borrower incentives drive noncompliance with mandated $8-\mathrm{K}$ disclosures.

\subsection{Cross-sectional tests - Firm auditor and industry competition}

Next, we present two cross-sectional tests to strengthen our inferences that the probability of withholding disclosure of high spread loans is decreasing in the cost of nondisclosure (H2). We expect that the relation between hidden loans and loan spreads is stronger when firms either have lower quality auditors (H2a) or operate in highly competitive industries (H2b). We compare the relation between spreads and Hidden Loan across partitions based on auditor reputation and industry competition.

The first three columns of Table 5 present the results for the auditor reputation partition. In particular, we use Big-4 auditors to proxy for more reputable auditors. We find about the same relation between loan spreads and nondisclosure among Big-4 and non-Big-4 auditors, suggesting that the incentive to withhold high spread loans does not differ with auditor quality. However, we find a stronger negative relation between loan size and nondisclosure among Big-4 auditors. The coefficient on Log Loan Amount is -0.066 in the Big-4 subsample and -0.019 in the non-Big-4 subsample. The difference between these two coefficients is statistically significant at the $1 \%$ level. This result suggests that firms with non-Big-4 auditors more often hide large loans than firms with Big-4 auditors. Further, our results on loan spread and loan size indicate that auditors' materiality decisions emphasize loan magnitude but no other informative characteristics, such as loan spreads.

The last three columns of Table 5 present the results for the industry competition partition. We partition our sample into firms in high competition industries and low competition industries based on the median Herfindahl index. The coefficient on Loan Spread in the high competition subsample is 
Table 4 Misclassified loans

Misclassified

(1)

(2)

\begin{tabular}{|c|c|c|}
\hline \multirow[t]{2}{*}{ Loan Spread } & $0.00630^{* *}$ & $0.00602^{* *}$ \\
\hline & $(2.32)$ & $(2.22)$ \\
\hline \multirow[t]{2}{*}{ Log Loan Amount } & -0.00117 & -0.00178 \\
\hline & $(-0.44)$ & $(-0.64)$ \\
\hline \multirow[t]{2}{*}{ Log Maturity } & -0.00371 & -0.00243 \\
\hline & $(-0.68)$ & $(-0.44)$ \\
\hline \multirow[t]{2}{*}{ Log Asset } & & 0.00655 \\
\hline & & $(0.94)$ \\
\hline \multirow[t]{2}{*}{ Equity Issue } & & -0.00411 \\
\hline & & $(-0.34)$ \\
\hline \multirow[t]{2}{*}{ ROA } & & $-0.277^{*}$ \\
\hline & & $(-1.65)$ \\
\hline \multirow[t]{2}{*}{ Book Leverage } & & 0.0170 \\
\hline & & $(0.59)$ \\
\hline \multirow[t]{2}{*}{ Loss } & & -0.00991 \\
\hline & & $(-1.17)$ \\
\hline \multirow[t]{2}{*}{ Z-Score } & & 0.00148 \\
\hline & & $(0.81)$ \\
\hline \multirow[t]{2}{*}{ Constant } & 0.0248 & -0.0218 \\
\hline & $(0.45)$ & $(-0.30)$ \\
\hline Observations & 11,136 & 10,840 \\
\hline R-squared & 0.448 & 0.462 \\
\hline Year FE & YES & YES \\
\hline Borrower FE & YES & YES \\
\hline Loan Type FE & YES & YES \\
\hline
\end{tabular}

This table reports the regression results of misclassified loans on loan spread. The dependent variable Misclassified is an indicator variable that equals 1 if the credit facility is disclosed in an 8-K filing but the item number is not 1.01 (material contract) or 2.03 (off-balance sheet facility). Hidden loans are excluded from this test. Appendix 2 defines the independent variables. Robust standard errors are clustered at package level. Each coefficient's t-statistic appears directly below the coefficient estimate. Statistical significance at the $1 \%$, $5 \%$, and $10 \%$ levels is denoted by ${ }^{* * *},{ }^{* *}$, and ${ }^{*}$, respectively

statistically larger than the coefficient in the low competition subsample $(\mathrm{p}<$ $1 \%$ ), suggesting that firms in highly competitive industries are more likely to withhold information on high spread loans. This result is consistent with the argument that competition increases the cost of disclosing proprietary information and, conversely, reduces the cost of nondisclosure. 
Table 5 Cross-sectional differences in loan disclosure

\begin{tabular}{|c|c|c|c|c|c|c|}
\hline & \multicolumn{2}{|c|}{ Hidden Loan } & \multirow{3}{*}{$\begin{array}{l}(1)-(2) \mathrm{z}- \\
\text { value }\end{array}$} & \multicolumn{2}{|l|}{ Hidden Loan } & \multirow{3}{*}{$\begin{array}{l}(4)-(5) \mathrm{Z}- \\
\text { value }\end{array}$} \\
\hline & (1) & (2) & & (4) & $(5)$ & \\
\hline & $\begin{array}{l}\text { Big } 4 \\
\text { auditor }\end{array}$ & $\begin{array}{l}\text { Non-Big } 4 \\
\text { auditor }\end{array}$ & & $\begin{array}{l}\text { High } \\
\text { competition }\end{array}$ & $\begin{array}{l}\text { Low } \\
\text { competition }\end{array}$ & \\
\hline Loan Spread & $\begin{array}{l}0.0329^{* * * *} \\
(5.83)\end{array}$ & $\begin{array}{l}0.0350^{\text {** }} \\
(2.58)\end{array}$ & -0.14 & $\begin{array}{l}0.0492^{\text {**** }} \\
(6.76)\end{array}$ & $\begin{array}{l}0.0173^{* *} \\
(2.47)\end{array}$ & $3.15^{* * * *}$ \\
\hline $\begin{array}{l}\text { Log Loan } \\
\text { Amount }\end{array}$ & $\begin{array}{l}-0.0663^{\text {**** }} \\
(-12.89)\end{array}$ & $\begin{array}{l}-0.0196 \\
(-1.40)\end{array}$ & $-3.15^{* * *}$ & $\begin{array}{l}-0.0644^{* * * *} \\
(-9.27)\end{array}$ & $\begin{array}{l}-0.0533^{* * * *} \\
(-8.04)\end{array}$ & -1.16 \\
\hline Log Maturity & $\begin{array}{l}-0.00581 \\
(-0.43)\end{array}$ & $\begin{array}{l}-0.0531 \\
(-1.26)\end{array}$ & 1.07 & $\begin{array}{l}0.00704 \\
(0.39)\end{array}$ & $\begin{array}{l}-0.0207 \\
(-1.13)\end{array}$ & 1.08 \\
\hline Log Asset & $\begin{array}{l}0.0400^{* * *} \\
(2.71)\end{array}$ & $\begin{array}{l}0.0392 \\
(0.85)\end{array}$ & 0.02 & $\begin{array}{l}0.00808 \\
(0.38)\end{array}$ & $\begin{array}{l}0.0679^{* * *} \\
(3.54)\end{array}$ & $-2.10^{* *}$ \\
\hline Equity Issue & $\begin{array}{l}-0.0512 \\
(-1.56)\end{array}$ & $\begin{array}{l}-0.0441 \\
(-0.47)\end{array}$ & -0.07 & $\begin{array}{l}-0.0729^{*} \\
(-1.66)\end{array}$ & $\begin{array}{l}-0.0435 \\
(-0.97)\end{array}$ & -0.47 \\
\hline ROA & $\begin{array}{l}-0.0653 \\
(-0.24)\end{array}$ & $\begin{array}{l}0.950 \\
(1.10)\end{array}$ & -1.13 & $\begin{array}{l}0.449 \\
(1.04)\end{array}$ & $\begin{array}{l}-0.303 \\
(-0.99)\end{array}$ & 1.42 \\
\hline Book Leverage & $\begin{array}{l}0.104^{*} \\
(1.69)\end{array}$ & $\begin{array}{l}-0.0477 \\
(-0.27)\end{array}$ & 0.81 & $\begin{array}{l}0.129 \\
(1.50)\end{array}$ & $\begin{array}{l}0.0698 \\
(0.93)\end{array}$ & 0.52 \\
\hline Loss & $\begin{array}{l}-0.0472^{* *} \\
(-2.51)\end{array}$ & $\begin{array}{l}0.0362 \\
(0.57)\end{array}$ & -1.26 & $\begin{array}{l}-0.0213 \\
(-0.82)\end{array}$ & $\begin{array}{l}-0.0599^{* *} \\
(-2.37)\end{array}$ & 1.07 \\
\hline Z-Score & $\begin{array}{l}0.00377 \\
(1.03)\end{array}$ & $\begin{array}{l}0.0138 \\
(1.35)\end{array}$ & -0.93 & $\begin{array}{l}0.00525 \\
(1.03)\end{array}$ & $\begin{array}{l}0.00798 \\
(1.55)\end{array}$ & -0.38 \\
\hline Constant & $\begin{array}{l}1.165^{\text {**** }} \\
(7.02)\end{array}$ & $\begin{array}{l}0.314 \\
(0.84)\end{array}$ & & $\begin{array}{l}2.086^{* * * *} \\
(6.44)\end{array}$ & $\begin{array}{l}0.605^{* *} \\
(2.50)\end{array}$ & \\
\hline Observations & 11,532 & 1,438 & & 6,613 & 6,617 & \\
\hline R-squared & 0.376 & 0.488 & & 0.412 & 0.387 & \\
\hline Year FE & YES & YES & & YES & YES & \\
\hline Borrower FE & YES & YES & & YES & YES & \\
\hline Loan Type FE & YES & YES & & YES & YES & \\
\hline
\end{tabular}

This table regresses Hidden Loan on loan characteristics in the subsamples based on Big-4 versus non-Big-4 auditors, and on industry competition. Columns (4) and (5) define High (low) competition as loans with an industry (two-digit SIC) Herfindahl lower (higher) than the median sample Herfindahl Index. We compute the z-yalues for the differences between coefficients as in Clogg et al. (1995), with $z=\left(b_{1}-b_{2}\right) /$

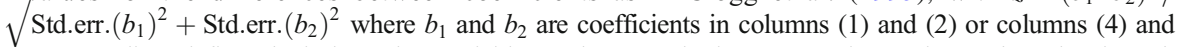
(5). Appendix 2 defines the independent variables. Robust standard errors are clustered at package level. Each coefficient's t-statistic appears directly below the coefficient estimate. Statistical significance at the $1 \%, 5 \%$, and $10 \%$ levels is denoted by ${ }^{* * *},{ }^{* *}$, and ${ }^{*}$, respectively

\section{Additional drivers of nondisclosure}

Table 6 presents regressions that examine other factors that can impact a firm's decision to withhold disclosure. First, we expect less withholding around acquisitions because investors expect borrowings concurrent with acquisitions (H3a). When investors expect 
the firm to have borrowings, they react more pessimistically to nondisclosure (e.g., Dye 1985; Jung and Kwon 1988). This pessimistic reaction reduces a firm's benefit from withholding adverse loan attributes. Second, we expect that firms are less likely to withhold loan disclosure when they are followed by more equity analysts (H3b). More scrutiny by analysts increases the likelihood of investors becoming aware of the loan, thereby reducing the benefit of withholding loan information. Third, we expect that firms are less likely to withhold loan disclosure when investors pay more attention to the $10-\mathrm{K}$ or $10-\mathrm{Qs}$ (H4). Fourth, we expect that firms are more likely to withhold disclosure of loans that include stringent financial covenants because of the covenants' potentially negative effects (H5).

Table 6 column (1) presents our results for asset acquisition (H3a). The independent variable Acquire Asset is an indicator variable that equals one if the loan is concurrent

Table 6 Additional drivers of nondisclosure

\begin{tabular}{|c|c|c|c|c|c|}
\hline & \multicolumn{5}{|c|}{ Hidden Loan } \\
\hline & _(1) & (2) & (3) & (4) & (5) \\
\hline Acquire Asset & $\begin{array}{l}-0.0299^{*} \\
(-1.93)\end{array}$ & & & & \\
\hline \# Analyst Following & & $\begin{array}{l}-0.0041^{* * *} \\
(-3.18)\end{array}$ & & & \\
\hline Log Downloads & & & $\begin{array}{l}-0.0199^{* *} \\
(-2.44)\end{array}$ & & \\
\hline Downloads $>$ Median & & & & $\begin{array}{l}-0.0381^{* * *} \\
(-3.11)\end{array}$ & \\
\hline Volatility & & & & & $\begin{array}{l}-0.460^{* * * *} \\
(-4.26)\end{array}$ \\
\hline Loan Spread & $\begin{array}{l}0.0345^{* * *} \\
(6.99)\end{array}$ & $\begin{array}{l}0.0316^{* * * *} \\
(6.47)\end{array}$ & $\begin{array}{l}0.0335^{* * * *} \\
(6.85)\end{array}$ & $\begin{array}{l}0.0338^{* * *} \\
(6.91)\end{array}$ & $\begin{array}{l}0.0378^{* * * *} \\
(7.39)\end{array}$ \\
\hline Log Loan Amount & $\begin{array}{l}-0.0604^{* * *} \\
(-12.63)\end{array}$ & $\begin{array}{l}-0.0614^{* * *} \\
(-12.88)\end{array}$ & $\begin{array}{l}-0.0621^{* * *} \\
(-12.89)\end{array}$ & $\begin{array}{l}-0.0621^{\text {*** }} \\
(-12.89)\end{array}$ & $\begin{array}{l}-0.0611^{\text {**** }} \\
(-12.62)\end{array}$ \\
\hline Log Maturity & $\begin{array}{l}-0.00930 \\
(-0.74)\end{array}$ & $\begin{array}{l}-0.0106 \\
(-0.84)\end{array}$ & $\begin{array}{l}-0.0113 \\
(-0.89)\end{array}$ & $\begin{array}{l}-0.0117 \\
(-0.92)\end{array}$ & $\begin{array}{l}-0.0124 \\
(-0.96)\end{array}$ \\
\hline Observations & 13,230 & 13,230 & 13,066 & 13,066 & 12,875 \\
\hline R-squared & 0.374 & 0.375 & 0.376 & 0.377 & 0.380 \\
\hline Firm Level Controls & YES & YES & YES & YES & YES \\
\hline Year FE & YES & YES & YES & YES & YES \\
\hline Borrower FE & YES & YES & YES & YES & YES \\
\hline Loan Type FE & YES & YES & YES & YES & YES \\
\hline
\end{tabular}

This table reports the results of regressing Hidden Loan on proxies for disclosure incentives and a set of control variables. The dependent variable Hidden Loan is a dummy variable that equals 1 if the loan is not disclosed in an 8-K. Appendix 2 defines the independent variables. Robust standard errors are clustered at the package level. Each coefficient's t-statistic appears directly below the coefficient estimate. Statistical significance at the $1 \%, 5 \%$, and $10 \%$ levels is denoted by ${ }^{* * * *},{ }^{* *}$, and ${ }^{*}$, respectively 
with asset acquisitions. ${ }^{27}$ The coefficient on Acquire Asset is negative and statistically significant at the $10 \%$ level $(\mathrm{t}=-1.93)$, suggesting that firms are less likely to withhold loan disclosures when investors expect that the firm obtained a loan. Column (2) presents our results for analyst following (H3b). The independent variable \# Analyst Following is the number of analysts following the firm in the year of taking the loan. The negative coefficient on \# Analyst Following suggests that more scrutiny by analysts reduces the benefits of hiding loan information (significant at 1\%).

Table 6 columns (3) and (4) present our results for investor attention (H4a). We measure investor attention by downloads from EDGAR (e.g., Drake et al. 2015; Loughran and McDonald 2017; Chen et al. 2020). Specifically, column (3) proxies for attention using the log number of downloads of Forms $10-\mathrm{K}$ and $10-\mathrm{Q}$ in the 6 months preceding the loan date, and column (4) uses an indicator for greater-thanmedian downloads during the six-month period. Consistent with $\mathrm{H} 4 \mathrm{a}$, we find negative coefficients for both of the download-based measures of attention (significant at $5 \%$ and $1 \%$, respectively).

Table 6 column (5) presents our results for volatility (H4b). The independent variable Volatility is a firm's stock return volatility in the six-month period before the loan starting month. The coefficient on Volatility is negative and statistically significant at the $1 \%$ level, suggesting that firms are less likely to withhold loans when they experience high volatility. This is consistent with investors paying more attention to firms' financial statements when the firm experiences high volatility (Chamberlain et al. 2005).

Table 7 presents our results related to financial covenants (H5). This table includes the 8174 loans with nonmissing covenant data in our sample. ${ }^{28}$ Panel A lists the proportions of loans with different financial covenant types. The most common are debt-to-EBITDA $(68 \%)$, interest coverage (41\%), and fixed charge coverage (34\%). Panel A also shows the proportion of loans with tight covenants, defined as the firm's financial metric within $10 \%$ of breaching the covenant threshold. The most common tight covenant by far is the debt-to-EBITDA, with $6.67 \%$ of firms having a ratio within $10 \%$ of the threshold.

Table 7 Panels $\mathrm{B}$ and $\mathrm{C}$ compare the number of covenants between hidden and disclosed loans. The univariate comparisons in Panel B show that hidden loans have about the same number of covenants as disclosed loans, but more tight covenants than disclosed loans (significant at 1\%). Panel $\mathrm{C}$ reports regression analysis. Column (1) shows that the number of tight covenants is positively associated with Hidden Loans (significant at 10\%). The dependent variable in column (2) is Hidden Loan (Ordered), which accounts for increasingly opaque disclosures. In this case, tight covenants are more strongly associated with nondisclosure (significant at 5\%). In untabulated robustness tests, we find similar results using 5\% and $15 \%$ thresholds for covenant tightness. ${ }^{29}$ Overall, these results are consistent with our hypothesis that firms are more likely to hide loans with tight covenants.

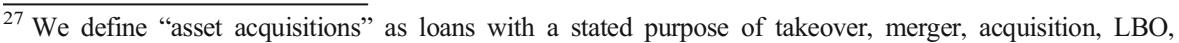
equipment purchases or capital expenditure.

${ }^{28}$ Christensen and Nikolaev (2012) document that Dealscan is unable to obtain covenant information on approximately $50 \%$ of loans. As a result, prior studies exclude these loans when studying financial covenants (e.g., Chava and Roberts 2008; Demerjian and Owens 2016; Saavedra 2019b).

${ }^{29}$ In addition, we find, in untabulated tests, a positive but statistically insignificant correlation between nondisclosure and the contractual weakness index (Demiroglu and James 2010; Bradley and Roberts 2015; Ivashina and Vallee 2020).
} 
竘

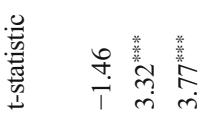

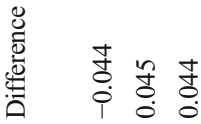

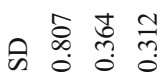

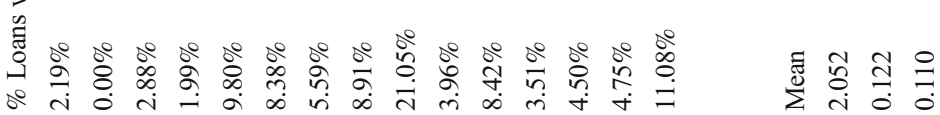

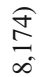

总

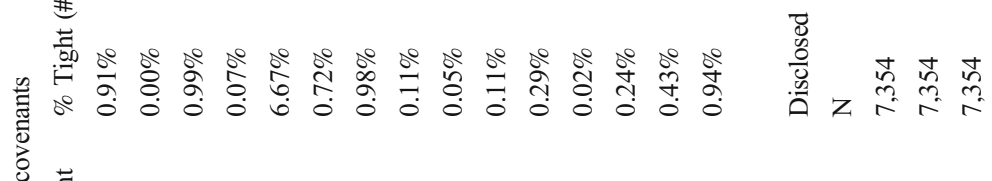

\#

$\frac{\mathcal{f}}{\frac{1}{\infty}}$

焉

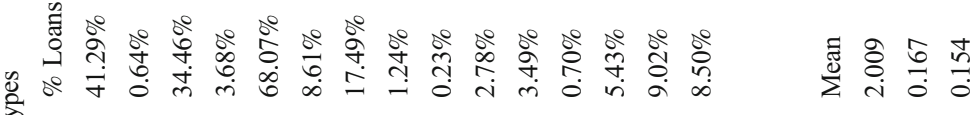

壳

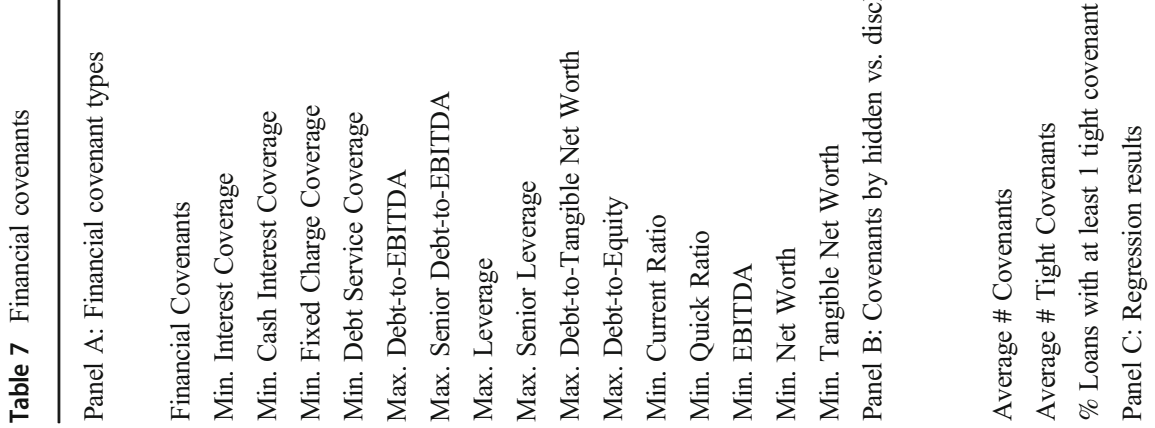




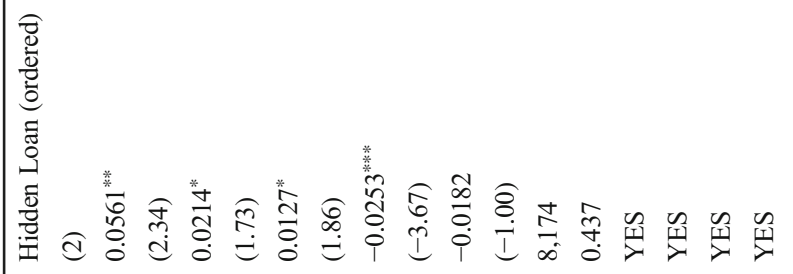

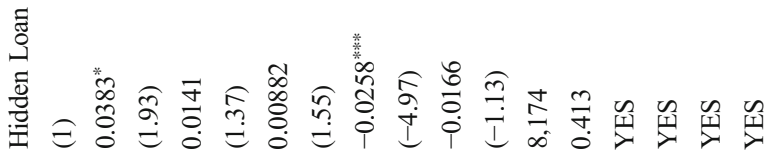

蒙

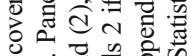

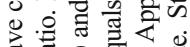

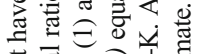

氜

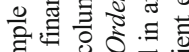

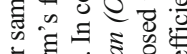

言目

. 쁠

के

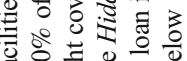

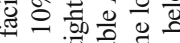

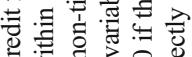

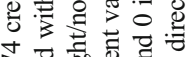

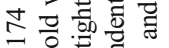

o)

च च

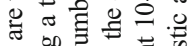

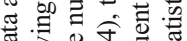

矛突导式

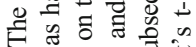

范

สี 뜰

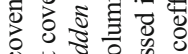

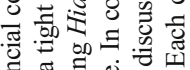

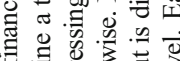

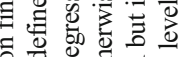

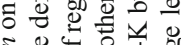

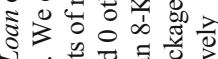

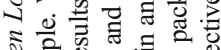

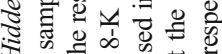

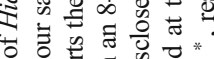

范

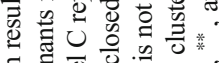

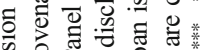

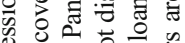

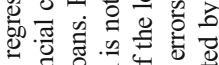

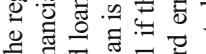

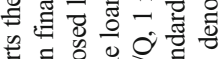

훙융

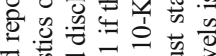

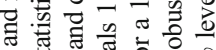

焉 覀焉

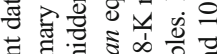

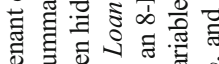

वृ

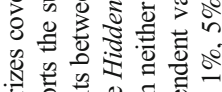

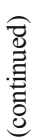

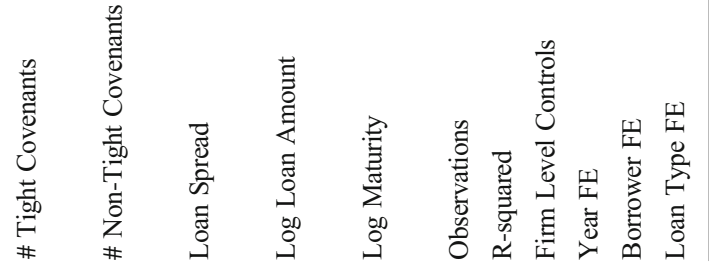

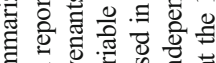

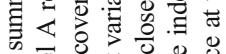

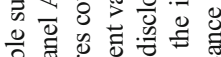

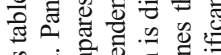

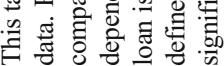




\section{Consequences of noncompliance}

This section sheds light on the costs of failing to comply with requirements to disclose loans in a Form 8-K. We first provide an examination of SEC comment letters, in which we find only one comment letter pertaining to a failure to disclose a loan in an 8$\mathrm{K}$. We then discuss the capital market consequences of nondisclosure.

We collect all SEC comment letters issued in the 12-month period following loan origination. Table 8 summarizes our data. Loan issuers received 12,735 comment letters within the 12 -month period following loan origination (untabulated), which pertain to issuers of 7100 of the 13,628 loans in our sample. To identify comment letters pertaining to the compliance of loan disclosure, we use a Python program to extract all comment letters that contain the keywords "credit agreement" (or its variations) and "8-K" (or "8 K") and refer to a loan date that is within 10 days of the loan starting date. ${ }^{30} \mathrm{We}$ then read these comment letters and identify those that discuss loan disclosure. We identify 74 credit facilities in our sample that are referred to in the comment letters. Only one of these letters refers to a failure to file an $8-\mathrm{K}$ disclosure of a loan. The remaining 73 loan-related comment letters pertain to disclosed loans. Forty of these refer to omitted exhibits and schedules in the loan contract; 31 are SEC requests for more disclosure of loan details, such as material terms and covenants; and two were sent for other reasons. ${ }^{31}$ Appendix 4 provides an example of a SEC comment letter on loan disclosure.

Aside from the one reference to a failure to file an 8-K, the SEC comment letters pertain to contracts that companies disclose rather than to companies' failure to disclose. In the context of our model in Appendix 1, this suggests that firms face a low cost for failing to file 8-K disclosures for loans. This, in turn, implies that firms whose loans reveal adverse information will avoid $8-\mathrm{K}$ disclosures even if there is a small impact on investors' ultimate ability to impound the adverse information into price.

Lastly, we study the effect of nondisclosure on capital markets. We first examine the stock market consequences. Table 9 Panel A reports Size/Book-toMarket adjusted monthly abnormal returns following loan issuance. Firms with hidden loans outperform firms with disclosed loans by $0.46 \%(\mathrm{t}=1.96)$ in the first month following the loan issuance. This outperformance reverses by the third month, as the firms with hidden loans underperform the firms with disclosed loans by $-0.49 \%(\mathrm{t}=2.18)$. This suggests that while firms with hidden loans enjoy a short-term benefit of withholding negative information, this information flows into stock prices in the longer term. We caution,

\footnotetext{
${ }^{0}$ In addition, we find, in untabulated tests, a positive but statistically insignificant correlation between nondisclosure and the contractual weakness index (Demiroglu and James 2010; Bradley and Roberts 2015; Ivashina and Vallee 2020).

${ }^{30}$ We use the 10-day window because sometimes the SEC will refer to the filing date of the loan, instead of the starting date of the loan.

${ }^{31}$ In one case, the SEC asks the firm to revise the exhibit index for the loan contract. In the other case, the SEC points out claims in the firm's proxy statement that are inconsistent with the loan disclosure.
} 
Table 8 SEC comment letters

\begin{tabular}{lllllll}
\hline & Total & \multicolumn{3}{c}{ Disclosed } & \multicolumn{2}{c}{ Hidden } \\
\hline Number of loans & 13,628 & $100 \%$ & 11,136 & $100 \%$ & 2,492 & $100 \%$ \\
Firm received comment letters & 7,100 & $52 \%$ & 5,777 & $52 \%$ & 1,323 & $53 \%$ \\
Received comment letters related to the loan & 74 & $1 \%$ & 73 & $1 \%$ & 1 & $1 \%$ \\
Detailed Breakdown of the 74 comment letters & & & & & \\
Omitted the schedules and exhibits & 40 & $54 \%$ & & & \\
Demand more details on the loan & 31 & $42 \%$ & & \\
Unsupportable statements & 1 & $1 \%$ & & & \\
Revise the exhibit index & 1 & $1 \%$ & & & \\
Fail to file an 8-K disclosure & 1 & $1 \%$ & & & \\
Total & 74 & $100 \%$ & & \\
\hline
\end{tabular}

This table reports detailed breakdowns of the comment letters received by borrowers in the 12-month period after loan issuance

however, that this return reversal should not be interpreted as the consequence of nondisclosure, as the equity market could be reacting to other information related to the loan, such as asset acquisition or liquidity problems.

Next, we examine how nondisclosure impacts the debt market. If hiding loans increases the adverse selection problem between borrowers and lenders, we expect that the borrowers' future loans will receive higher spreads if they fail to disclose loans. We match each loan in our sample to the next loan the borrower takes within 12 months following the current loan. Approximately $30 \%$ of the borrowers take a new loan, and the average (median) number of days from the current loan starting date to the new loan starting date is 230 (236).

Table 9 Panel B reports the results. The dependent variable Future Spread is the spread on the next loan taken by the borrower in the next 12-month period. In columns (1) and (2), the independent variable Hidden Loan is an indicator variable that equals one if the current loan is a hidden loan. The coefficient on Hidden Loan is positive but not statistically significant when controlling for various loan-level and firm-level characteristics. In columns (3) and (4), we use Hidden Loan (Ordered) as the independent variable. Hidden Loan (Ordered) is a categorical variable increasing in the opacity of disclosure as it puts more weight on loans that are neither disclosed in $8-\mathrm{K}$ nor $10-\mathrm{K} / \mathrm{Q}$. We find that future spread is increasing in the opacity of the loan disclosure, and this positive correlation is robust to various loan-level and firm-level controls.

Overall, our equity market and debt market results suggest that managers benefit from hiding loans via a delay in revealing negative information to the equity market, which comes at the cost of higher loan spreads in the future. Our analysis of SEC comment letters suggests little to no regulatory cost of failing to file Form 8-K, making higher loan spreads the only cost we document. 
Table 9 Capital market implications of hidden loans

Panel A: Equity market implications - Market returns following loan initiation

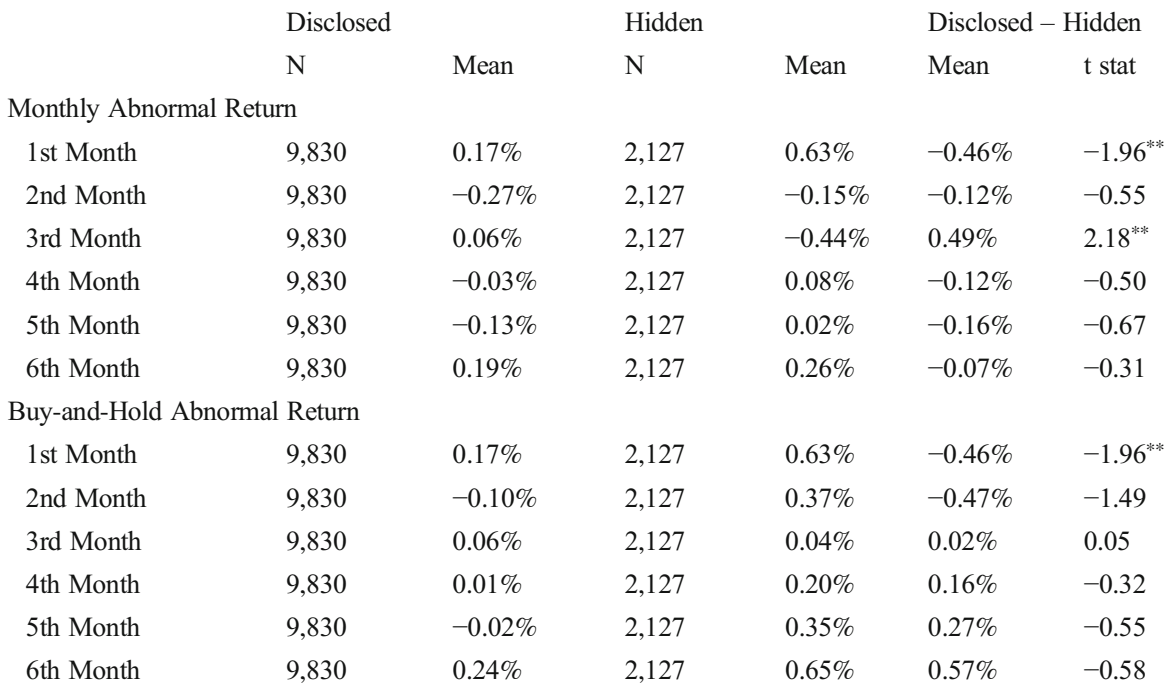

Panel B: Debt market implications - Future spreads

\section{Future Spread}

Hidden Loan indicator

(1)

Hidden Loan

$0.1072^{*}$

(1.82)

(2)

(1.82) (0.73)

Loan Spread

$0.1259^{\text {**** }}$

Log Loan Amount

Log Maturity

$-0.0583^{* *}$

$(-2.20)$

$-0.0648$

$(-1.15)$

Constant

$1.9156^{* * * *}$

$3.6581^{\text {**** }}$

(11.22)

(4.76)

Observations

3,966

3,842

R-squared

0.806

0.815

Firm Level Controls

Year FE

Borrower FE

Loan Type FE
NO

YES

YES

YES
YES

YES

YES

YES
Hidden Loan (Ordered)

(3) (4)

$0.1547^{* * *} \quad 0.1064^{* *}$

(2.87) (2.00)

$0.1223^{\text {**** }}$

(2.75)

$-0.0522^{\text {*** }}$

$(-2.04)$

$-0.0653$

$(-1.16)$

$1.8980^{* * *} \quad 3.5588^{* * *}$

(11.37) (4.65)

$3,966 \quad 3,842$

$0.807 \quad 0.816$

NO YES

YES YES

YES YES

YES YES

a The monthly abnormal return equals the borrower's less the return on size-book/market matched portfolio (10x10 portfolios). Buy-and-hold abnormal return $($ BHR $)=$ Borrower's BHR - BHR on size-book/market matched portfolio (10x10 portfolios). Data on size and book/market portfolio break points and returns is retrieved from Kenneth French's website. We require non-missing abnormal returns in the six-month period following the loan starting date.

Panel A reports the Size-Book/Market adjusted abnormal monthly return for the 6 months following the loan starting date. ${ }^{\mathrm{a}}$ Panel $\mathrm{B}$ reports the regression results of future spread on hidden loan. The dependent variable 
Future Spread is the spread of the next loan the borrower takes in the 12-month period following the current loan. The independent variable Hidden Loan is an indicator variable equal to one if the loan is not disclosed in the $8 \mathrm{~K}$. Hidden Loan (Ordered) equals 2 if the loan is disclosed in neither an $8-\mathrm{K}$ nor a 10-K/Q, 1 if the loan is not disclosed in an $8-\mathrm{K}$ but is discussed in a subsequent $10-\mathrm{K} / \mathrm{Q}$, and 0 if the loan is disclosed in an $8-\mathrm{K}$. Robust standard errors are clustered at package level. Each coefficient's t-statistic appears directly below the coefficient estimate. Statistical significance at the $1 \%, 5 \%$, and $10 \%$ levels is denoted by ${ }^{* * *},{ }^{* *}$, and ${ }^{*}$, respectively

\section{Conclusion}

This study sheds light on firms' choices of whether to comply with the SEC's disclosure rules, specifically as they pertain to disclosing borrowings in Form 8-K filings. We find that firms are more likely to hide loans that reveal adverse information, as proxied by high spreads and stringent financial covenants. We also find that large firms typically borrow in amounts that are small relative to their company size, which may give them room to withhold disclosure on the grounds that the loans are immaterial. To the extent that this drives some of their nondisclosure, it appears that the firms interpret materiality somewhat opportunistically and use a lower materiality threshold for low-spread loans than for high-spread loans. While our paper focuses on the setting of loan disclosures, it has implications for other mandatory disclosure settings where firms have discretion in how they interpret the materiality threshold (e.g., other types of contracts, impairment, etc.), as the endogenous nature of "mandatory" disclosure can create biases in the first stage sample selection.

Our cross-sectional results show that firms are less likely to hide loans when investors anticipate borrowing during asset acquisitions, when firms are followed by more equity analysts or receive more investor attention, and when firms experience high volatility. The relation between spreads and hidden loans is stronger in the subsample of firms in more competitive industries, consistent with firms hiding loans when they have greater incentives to do so.

This paper contributes to the disclosure literature by providing direct evidence that managers withhold bad news (i.e., high spread loans), consistent with the results in Kothari et al. (2009). Further, we examine the tradeoffs faced by the firm when it decides whether to comply with the mandatory disclosure requirement. On the one hand, withholding 8-K disclosure obscures the loan characteristics and makes it less likely that investors will impound them into price. This can, at least temporarily, benefit managers if the loan characteristics reveal negative information about the firm. On the other hand, managers who withhold disclosure face potential regulatory and capital market consequences. In an appendix, we present a parsimonious model that formalizes our hypotheses and provides novel predictions on disclosure incentives. Our empirical results are largely consistent with the model's predictions. This paper is novel in that it focuses on the incentives related to the omission of mandatory disclosures. We document that firms withhold loan disclosure even though it is mandated by the regulator, and that these hidden loans are not captured by the SEC's enforcement process. Moreover, our findings suggest that firms appear to exploit the ambiguous definition of materiality (Georgiev 2017). 


\section{Appendix 1 Model}

This appendix presents the model that formally develops our hypotheses in Section 3.1. A manager wishes to maximize price as set by competitive, risk-neutral investors. The timeline is as follows:

\section{Figure A1: Timeline}

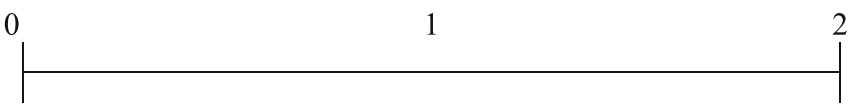

Manager obtains a highspread loan (event $B$ ) with probability $\beta$, and possibly discloses
Manager reports $s$ and investors set price $p=\mathrm{E}[v \mid s$, Disclosure $]$
Investors receive terminal payoff $v$

Investors have the prior belief that firm value $v$ is normally distributed with variance $\sigma_{v}^{2}$. As we discuss in Section 3.1, if the firm borrows at a high spread, this conveys negative information about the firm. We model this by:

$$
\mathrm{E}[v]= \begin{cases}\mu_{v}-b & \text { If high-spread borrowing (event } B), \\ \mu_{v} & \text { If no borrowing or borrowing at typical spread }(\neg \mathrm{B}) .\end{cases}
$$

The manager is required to directly disclose any borrowings, and incurs an expected cost $c$ for failing to do so. The cost $c$ represents costs of noncompliance such as litigation or censure from the SEC. The manager also produces a mandatory report $s=v+e$ where $e$ is normally distributed with mean zero and variance $\sigma_{e}^{2}$. The mandatory report $s$ can be viewed as the 10$\mathrm{K}$ or 10-Q. Even if the manager does not directly disclose any loans, loans will impact the signal $s$. This provides a noisy inference about borrowing that can represent the loans' impact on net income, being buried in the financial statement notes, and so forth.

Risk-neutral investors value the firm based on available information, and the manager seeks to maximize share price. If investors know whether or not $B$ has occurred, then the share price is either:

$$
\mathrm{E}[v \mid s, B]=\frac{\sigma_{e}^{2}\left(\mu_{v}-b\right)+\sigma_{v}^{2} s}{\sigma_{v}^{2}+\sigma_{e}^{2}}, \quad \text { or } \quad \mathrm{E}[v \mid s, \neg B]=\frac{\sigma_{e}^{2} \mu_{v}+\sigma_{v}^{2} s}{\sigma_{v}^{2}+\sigma_{e}^{2}} .
$$

If investors do not know whether or not $B$ has occurred, then the share price is:

$$
\begin{aligned}
\mathrm{E}[v \mid s] & =\mathrm{E}[v \mid s, B] \mathrm{P}(B \mid s)+\mathrm{E}[v \mid s, \neg B] \mathrm{P}(\neg B \mid s) \\
& =\mathrm{E}[v \mid s, B]+\underbrace{\frac{\sigma_{e}^{2} b}{\sigma_{v}^{2}+\sigma_{e}^{2}}}_{\mathrm{E}[v \mid s, \neg B]-\mathrm{E}[v \mid s, B]} \frac{1}{1+\frac{\beta}{1-\beta} \exp \left\{-\frac{b}{\sigma_{v}^{2}+\sigma_{e}^{2}}\left(s-\mu_{v}+\frac{b}{2}\right)\right\}}
\end{aligned}
$$

Expression (A3) illustrates how investors use the signal $s$ to infer whether or not $B$ has occurred, where $\mathrm{E}[v \mid s]$ approaches $\mathrm{E}[v \mid s, \neg B](\mathrm{E}[v \mid s, B])$ as $s \rightarrow \infty(s \rightarrow-\infty)$. 
(6) When $B$ occurs, the manager does not yet know the realization of the mandatory report $s$, and withholds disclosure if the expected price impact exceeds the cost:

$$
\underbrace{\mathrm{E}[\mathrm{P}(\neg B \mid s) \mid B] \frac{\sigma_{e}^{2}}{\sigma_{v}^{2}+\sigma_{e}^{2}}}_{\mathrm{E}[\mathrm{E}[v \mid s]-\mathrm{E}[v \mid s, B] \mid B]} b>c .
$$

In expression (A4), the benefit of withholding disclosure has two components: investors' expected probability $\mathrm{E}[\mathrm{P}(\neg B \mid s) \mid B]$ of the negative event $B$ not happening given the report, and the benefit $\mathrm{E}[v \mid s, \neg B]-\mathrm{E}[v \mid s, B]=\frac{\sigma_{e}^{2}}{\sigma_{v}^{2}+\sigma_{e}^{2}}$ bof investors failing to recognize that $B$ has occurred. The structure resembles Dye (1985) and Jung and Kwon (1988) except that there is uncertainty about the occurrence of an event, rather than about the manager being informed.

The preceding model implies the following comparative statics:

1) The benefit of withholding is decreasing in the prior probability $\beta$ of the firm obtaining a high-spread loan.

Proof The value $\mathrm{E}[\mathrm{E}[v \mid s]-\mathrm{E}[v \mid s, B] \mid B]$ of nondisclosure can be written as follows, where $z=\frac{s-\left(\mu_{v}+b\right)}{\sqrt{\sigma_{v}^{2}+\sigma_{e}^{2}}}, \widehat{b}=\frac{b}{\sqrt{\sigma_{v}^{2}+\sigma_{e}^{2}}}$, and $\phi(\bullet)$ denotes the pdf of a standard normal:

$$
\mathrm{E}[\mathrm{E}[v \mid s]-\mathrm{E}[v \mid s, B] \mid B]=\frac{\sigma_{e}^{2}}{\sqrt{\sigma_{v}^{2}+\sigma_{e}^{2}}} \hat{b} \underbrace{\int_{-\infty}^{\infty} \frac{1}{1+\frac{\beta}{1-\beta} \mathrm{e}^{-\hat{b}\left(z-\frac{1}{2} \hat{b}\right)} \phi(z) \mathrm{d} z} .}_{f(\hat{b}, \beta)=\mathrm{E}[\mathrm{P}(\neg B \mid s) \mid B]}
$$

Straightforward computations show that $f(\widehat{b}, \beta)$ is decreasing in $\beta$.

2) The benefit of withholding is increasing and concave in the impact $b$ of obtaining a high-spread loan on expected firm value, provided that $b$ is sufficiently small (less than about 1.6 standard deviations $\sqrt{\sigma_{v}^{2}+\sigma_{e}^{2}}$ of the report $s$ ).

Proof The proof is numerical. Figure 2 Panel A shows that $\widehat{b} f(\widehat{b}, \beta)$ is a single-peaked function for all values of $\beta$. Panel B shows that the peak $\widehat{b}$ is above about 1.6 for all values of $\beta$, implying that $\widehat{b} f(\widehat{b}, \beta)$ is increasing in $\widehat{b}$ for all $\widehat{b}<1.6$ or, equivalently, for all $b<1.6 \sqrt{\sigma_{v}^{2}+\sigma_{e}^{2}}$. 
a $\hat{\boldsymbol{b}} \boldsymbol{f}(\hat{\boldsymbol{b}}, \boldsymbol{\beta})$ as a function of $\hat{\boldsymbol{b}}$

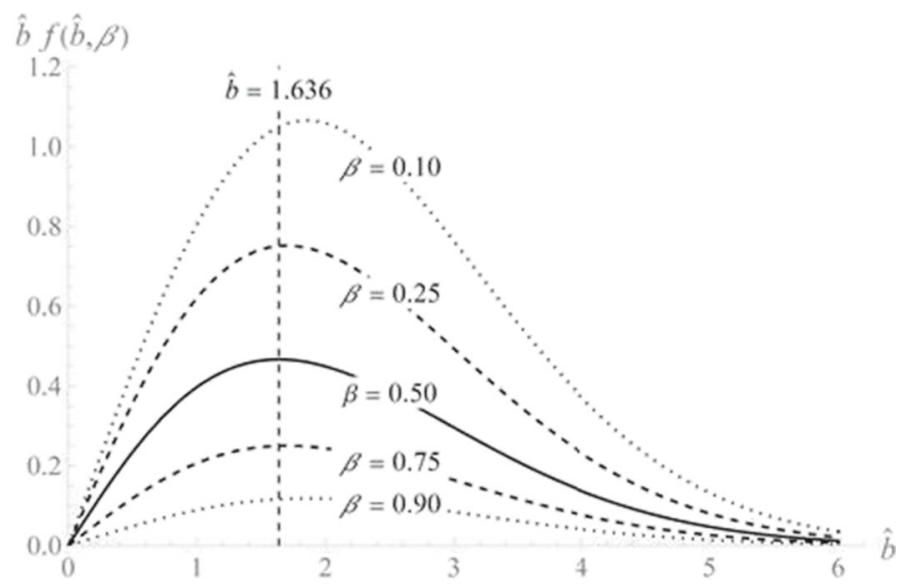

b Maximizing $\hat{\boldsymbol{b}}^{*}=\operatorname{argmax} \hat{b} f(\hat{b}, \beta)$ as a function of $\beta$

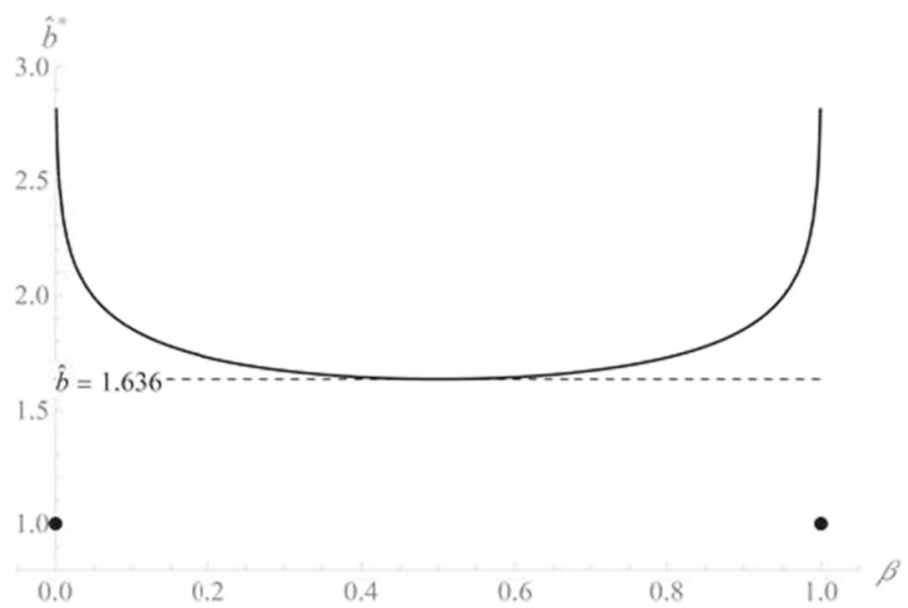

Fig. 2 Panel $\widehat{A}_{*}$ A plots $\widehat{b} f(\widehat{b}, \beta)$ from expression (A5) for different values of the prior $\beta=\mathrm{P}(B)$. Panel B plots the values $\widehat{b}$ that maximize $\widehat{b} f(\widehat{b}, \beta)$. Panel $A: \widehat{\mathbf{b}} \boldsymbol{f}(\widehat{\mathbf{b}}, \boldsymbol{\beta})$ as a function of $\widehat{\mathbf{b}}$. Panel $B$ : Maximizing $\widehat{\boldsymbol{b}}=$ $\operatorname{argmax} \widehat{b} \boldsymbol{f}(\widehat{b}, \boldsymbol{\beta})$ as a function of $\beta$

To illustrate the forces, we have:

$$
\frac{\mathrm{d} \widehat{b} f(\widehat{b}, \beta)}{\mathrm{d} \widehat{b}}=f(\widehat{b}, \beta)+\widehat{b} \frac{\partial f(\widehat{b}, \beta)}{\partial \widehat{b}} .
$$


The substitution $\zeta=z-\widehat{b}$ allows $\frac{\partial f(\widehat{b}, \beta)}{\partial \hat{b}}$ to be written as:

$$
\frac{\partial f(\widehat{b}, \beta)}{\partial \widehat{b}}=\frac{\beta}{1-\beta} \int_{-\infty}^{\infty}\left(\frac{\mathrm{e}^{-\widehat{b}\left(\zeta+\frac{\hat{1}}{2}\right)}}{1+\mathrm{e}^{-\widehat{b}\left(\zeta+\frac{1}{2}\right)} \frac{\beta}{1-\beta}}\right)^{2} \zeta \phi(\xi) \mathrm{d} \zeta<0
$$

where the inequality follows because the squared term that multiplies $\zeta$ is decreasing in $\zeta$. At $\widehat{b}=0, f(\widehat{b}, \beta)=1-\beta$ and $\frac{\partial f(\widehat{b}, \beta)}{\widehat{\partial b}}=0$ so that $\frac{\widehat{\mathrm{d} b} f(\widehat{b}, \beta)}{\widehat{\mathrm{d} b}}=1-\beta$. As $\widehat{b} \rightarrow \infty, f$ $(\widehat{b}, \beta) \rightarrow 0$ and $\frac{\partial f(\widehat{b}, \beta)}{\widehat{\partial b}}$ again approaches zero but remains negative so that $\frac{\widehat{\mathrm{d} b} f(\widehat{b}, \beta)}{\widehat{\mathrm{d} b}}$ becomes negative.

3) The benefit of withholding is increasing in the noisiness $\sigma_{e}^{2}$ of the financial statements and, when the impact of $b$ is sufficiently small relative to typical variation in the firm's report (less than about 1.6 standard deviations $\sqrt{\sigma_{v}^{2}+\sigma_{e}^{2}}$ of the report $s$ ), the benefit of withholding is decreasing in the volatility $\sigma_{v}^{2}$ of the company value.

Proof Differentiating the value of nondisclosure gives:

$$
\begin{aligned}
& \frac{\mathrm{dE}[\mathrm{E}[v \mid s]-\mathrm{E}[v \mid s, B] \mid B]}{\mathrm{d} \sigma_{e}^{2}}=\frac{\sigma_{e}^{2}}{\left(\sigma_{v}^{2}+\sigma_{e}^{2}\right)^{3 / 2}}\left(\frac{\sigma_{v}^{2}}{\sigma_{e}^{2}}-\frac{1}{2} \frac{\widehat{b}}{f(\widehat{b}, \beta)} \frac{\partial f(\widehat{b}, \beta)}{\partial \widehat{b}}\right) \widehat{b} f(\widehat{b}, \beta)>0, \\
& \frac{\mathrm{dE}[\mathrm{E}[v \mid s]-\mathrm{E}[v \mid s, B] \mid B]}{\mathrm{d} \sigma_{v}^{2}}=-\frac{1}{2} \frac{\sigma_{e}^{2}}{\left(\sigma_{v}^{2}+\sigma_{e}^{2}\right)^{3 / 2}}\left(f(\widehat{b}, \beta)+\frac{\mathrm{d} b f(\widehat{b}, \beta)}{\mathrm{d} \widehat{b}}\right) \widehat{b} .
\end{aligned}
$$

The first inequality is implied by $\frac{\partial f(\widehat{b}, \beta)}{\partial \hat{b}}<0$, as shown in \#2. For the derivative with respect to $\sigma_{v}^{2}, \frac{\mathrm{d} b f(\widehat{b}, \beta)}{\widehat{\mathrm{d} b}}>0$ is a sufficient condition guaranteed by $b$ being sufficiently small. 


\section{Variable definitions}

\begin{tabular}{|c|c|}
\hline Variable Names & Definition \\
\hline Hidden Loan & An indicator variable equal to one if the credit facility is not disclosed in $8-\mathrm{K}$ \\
\hline $\begin{array}{l}\text { Hidden Loan } \\
\text { (Ordered) }\end{array}$ & $\begin{array}{l}\text { Categorical variable equal to zero if the credit facility is disclosed, equal to one if credit } \\
\text { facility is not disclosed in } 8-\mathrm{K} \text { but discussed in } 10-\mathrm{K}(10-\mathrm{Q}) \text {, equal to two if the credit } \\
\text { facility is neither disclosed in } 8-\mathrm{K} \text { nor } 10-\mathrm{K}(10-\mathrm{Q})\end{array}$ \\
\hline Misclassified Loan & $\begin{array}{l}\text { An indicator variable equal to one if the credit facility is disclosed in } 8 \text {-K but the item } \\
\text { number is not } 1.01 \text { (material contract) or } 2.03 \text { (off-balance sheet facility) }\end{array}$ \\
\hline Loan Spread & $\begin{array}{l}\text { Loan spread is measured as all-in spread drawn in the DealScan database. All-in spread } \\
\text { drawn is defined as the amount the borrower pays in basis points over the London } \\
\text { Interbank Borrowing Rate (LIBOR) or the LIBOR equivalent for each dollar drawn } \\
\text { down }\end{array}$ \\
\hline
\end{tabular}

Loan Amount (\$M) The loan amount measured in millions of dollars

Maturity

The maturity of the loan, which is measured in months

Loan to Asset

Loan Amount divided by total asset at the quarter end before loan starting date

Log Asset

Equity Issue

Log of total assets, measured at the quarter end before loan starting date

An indicator variable equal to one if the loan is made in the month of or in the month before an equity offering

$R O A$

Net Income /Total Asset, measured at the quarter end before loan starting date

Book Leverage

Total Debt/Total Assets, measured at the quarter end before loan starting date

Loss

An indicator variable equal to one if the net income in the quarter before loan starting date is negative

Z_Score

Altman (1968) Z-score, measured at the quarter end before loan starting date. Following Roberts $(2015), \mathrm{Z}$ score $=1.2 \times[(\mathrm{actq}-\mathrm{lctq}) / \mathrm{atq}]+1.4 \times($ req $/ \mathrm{atq})+3.3 \times(\mathrm{piq} / \mathrm{atq})+0.6 \times$ $[(\mathrm{prccq} \times \mathrm{cshoq}) / \mathrm{ltq}]+0.999 \times(\mathrm{saleq} / \mathrm{atq})$

Herfindal Index The sum of the squared market share of each Compustat company in a particular two-digit SIC code. Market share=sales of a particular company divided by the total sales of the SIC code

Big 4

Acquire Asset

An indicator variable equal to one if the auditor is a big 4 auditor

An indicator variable equal to one if loan purpose is takeover, merger, acquisition line, LBO, equipment purchases, or capital expenditure, per Dealscan.

\# of Analysts Number of analysts that issue at least one annual EPS in the loan starting year. The data is retrieved from IBES.

Volatility

The standard deviation of monthly return in the six-month period before the loan starting month. We require at least five non-missing monthly returns. The data is retrieved from CRSP.

EDGAR

Downloads

\# Financial

Average number of EDGAR downloads of the borrower's periodic reports (Form 10-K and 10-Q) filed within the 6 months prior to the loan date. The data is from the SEC Log File Data Set. We follow Ryans 2017's method to clean the log file and exclude downloads from robot IP addresses.

Covenants

Number of the financial covenants, per Dealscan. 


\begin{tabular}{ll}
\hline $\begin{array}{l}\text { Variable Names } \\
\text { \# Tight Covenants }\end{array}$ & $\begin{array}{l}\text { Definition } \\
\text { Number of financial covenants where the borrower's financial ratio, as defined in } \\
\text { Demerjian and Owens (2016), Table 4) is within 10\% of the covenant threshold given } \\
\text { in Dealscan. }\end{array}$ \\
$\begin{array}{l}\text { \# Non-Tight Cove- } \\
\text { nants }\end{array}$ & \# Financial Covenants - \# Tight Covenants \\
\hline
\end{tabular}

\section{Examples of undisclosed loans and misclassified loans}

\section{Example 1: loan that is not disclosed in 8-K but is discussed in subsequent $10-\mathrm{K}$ (or 10-Q). ${ }^{32}$}

RadNet does not issue an 8-K for its $\$ 35$ million loan with a 9\% spread originated on February 22, 2008 (facilityid 233,019). The information of this loan is buried in the 10$\mathrm{K}$ issued on April 1, 2008, with the following sentence:

On February 22, 2008, we secured an incremental \$35 million ("Second Incremental Facility") as part of our existing credit facilities with GE Commercial Finance Healthcare Financial Services. The Second Incremental Facility consists of an additional $\$ 35$ million as part of our second lien term loan and the ability to further increase the second lien term loan by up to $\$ 25$ million and the first line term loan or revolving credit facility by up to an additional $\$ 40$ million sometime in the future. As part of the transaction, partly due to the drop in LIBOR of over $2.00 \%$ since the credit facilities were established in November 2006, we increased the Applicable LIBOR Margin to $4.25 \%$ for the revolving credit facility and the term loan and $9.0 \%$ for the second lien term loan. The additions to RadNet's existing credit facilities are intended to provide capital for near-term opportunities and future expansion.

\section{Example 2: loan that is neither disclosed in 8-K nor discussed in $10-\mathrm{K}$ (or $10-\mathrm{Q}) .^{33}$}

Celadon Group Inc. does not provide any information on a January 14, 2005, loan (facilityid 176,174) in an 8-K or 10-K (10-Q). The spread is $2.5 \%$ (all other loans taken by Celadon Group have spreads below $1 \%$ ), and the amount is $\$ 10 \mathrm{M}$. Dealscan lender data shows that the loan is syndicated by Bank of America.

In the first quarter 10-Q filed on May 6, 2005, the company discusses its liquidity and capital resources on p. 19 (quoted below), and there is no mention of this loan.

On September 26, 2002, we entered into our current primary credit facility with Fleet Capital Corporation, Fleet Capital Canada Corporation and several other lenders. This $\$ 55.0$ million facility consists of revolving loan facilities, approximately $\$ 9.4$ million in loan subfacilities, and a commitment to issue and guaranty letters of credit. Repayment of the amounts outstanding under the credit facility is secured by a lien on our assets, including the stock or other equity interests of our subsidiaries, and the

\footnotetext{
32 Source: https://www.sec.gov/Archives/edgar/data/790526/000101968708001442/0001019687-08-001442index.htm

33 Sources: https://www.sec.gov/Archives/edgar/data/865941/000100888605000117/form10q.htm, https:// www.sec.gov/Archives/edgar/data/865941/000100888605000009/cldnform8k.htm.
} 
assets of certain of our subsidiaries. In addition, certain of our subsidiaries that are not party to the credit facility have guaranteed the repayment of the amount outstanding under the credit facility, and have granted a lien on their respective assets to secure such repayment. The credit facility expires on September 26, 2005.

On p. 10 of the 10-Q, the company writes:

On January 14, 2005, the Company purchased certain assets consisting of approximately 370 tractors and 670 van trailers of CX Roberson, Inc. ("Roberson") for approximately $\$ 22.7$ million. The Company used borrowings under its existing credit facility to fund the transaction. The transaction did not include Roberson's flatbed business and related assets.

The information on asset acquisition is disclosed in an 8-K filed on January 21 , 2005 , but the disclosure does not provide any information on the $\$ 10$ million loan.

\section{Example 3: misclassified loans. ${ }^{34}$}

Item 8.01 Other Events.

On June 19, 2013, McGraw Hill Financial, Inc. (the "Company") entered into a $\$ 1,000,000,000$ Four-Year Credit Agreement, dated as of June 19, 2013 (the "Credit Agreement"), among the Company, Standard \& Poor's Financial Services LLC ("S\&P"), a wholly-owned subsidiary of the Company, as guarantor, the lenders listed thereon, JPMorgan Chase Bank N.A., as administrative agent, and Bank of America, N.A., as syndication agent. The Credit Agreement replaces the Company's existing $\$ 1,200,000,000$ Three-Year Credit Agreement, dated as of July 30, 2010.

The Credit Agreement contains customary affirmative and negative covenants, and includes customary events of default. The occurrence of an event of default could result in an acceleration of the obligations under the Credit Agreement.

\section{Examples of SEC comment letters on loan disclosure ${ }^{35}$}

On April 3, 2012, Raymond James Financial disclosed the credit agreement in 8-K item 1.01 , but the credit agreement attached in the $8-\mathrm{K}$ does not have exhibits.

On April 10, 2012, SEC issued a comment letter regarding the Form 8-K filed April 3, 2012:

You omitted the exhibits and schedules to the credit agreement filed as Exhibit 10.22 to the Form 8-K. Please amend the Form 8-K and refile the credit agreement in its entirety.

Acknowledgements We thank Peter Demerjian, Henry Friedman, Carla Hayn, Scott Richardson (the editor), Brett Trueman, Joe Weber, an anonymous referee, and seminar participants at LSE and Rice for helpful comments. We also thank Bret Johnson for valuable institutional information about the SEC.

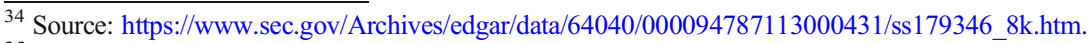

${ }^{35}$ Sources: https://www.sec.gov/Archives/edgar/data/720005/000119312512146517/0001193125-12146517-index.htm

https://www.sec.gov/Archives/edgar/data/720005/000000000012018163/0000000000-12-018163-index. htm 
Open Access This article is licensed under a Creative Commons Attribution 4.0 International License, which permits use, sharing, adaptation, distribution and reproduction in any medium or format, as long as you give appropriate credit to the original author(s) and the source, provide a link to the Creative Commons licence, and indicate if changes were made. The images or other third party material in this article are included in the article's Creative Commons licence, unless indicated otherwise in a credit line to the material. If material is not included in the article's Creative Commons licence and your intended use is not permitted by statutory regulation or exceeds the permitted use, you will need to obtain permission directly from the copyright holder. To view a copy of this licence, visit http://creativecommons.org/licenses/by/4.0/.

\section{References}

Altman, E. (1968). Financial ratios, discriminant analysis and the prediction of corporate bankruptcy. Journal of Finance 23 (4): 589-609.

Angrist, J., and J. Pischke. (2009). Mostly harmless econometrics: An Empiricist's companion. Princeton University Press.

Bens, D., M. Cheng, and M. Neamtiu. (2016). The impact of SEC disclosure monitoring on the uncertainty of fair value estimates. The Accounting Review 91 (2): 349-375.

Beyer, A., D. Cohen, T. Lys, and B. Walther. (2010). The financial reporting environment: Review of the recent literature. Journal of Accounting and Economics 50 (2-3): 296-343.

Bird, A., S. Karolyi, and P. Ma. (2018). Strategic disclosure misclassification. Available at SSRN: https:// papers.ssrn.com/sol3/papers.cfm?abstract_id=2778805. Revised January 19, 2018.

Boone, A., I. Floros, and S. Johnson. (2016). Redacting proprietary information at the initial public offering. Journal of Financial Economics 120 (1): 102-123.

Bradley, M., and M. Roberts. (2015). The structure and pricing of corporate debt covenants. The Quarterly Journal of Finance 5 (02): 1550001.

Carter, M., and B. Soo. (1999). The relevance of form 8-K reports. Journal of Accounting Research 37 (1): 119-132.

Cassell, C., L. Dreher, and L. Myers. (2013). Reviewing the SEC's review process: 10-K comment letters and the cost of remediation. The Accounting Review 88 (6): 1875-1908.

Chamberlain, D., R. Freeman, and A. Koch. (2005). The effect of risk on price responses to unexpected earnings. Journal of Accounting, Auditing and Finance 20 (4): 461-482.

Chava, S., and M. Roberts. (2008). How does financing impact investment? The role of debt covenants. Journal of Finance 63 (5): 2085-2121.

Chen, G., X. Tian, and M. Yu. (2019). Redact to protect? Customers' incentive to protect information and suppliers' disclosure strategies. Available at SSRN: https://papers.ssrn.com/sol3/Papers.cfm?abstract_id= 3195014. Revised February 28, 2019.

Chen, H., L. Cohen, U. Gurun, D. Lou, and C. Malloy. (2020). IQ from IP: Simplifying search in portfolio choice. Journal of Financial Economics 138 (1): 118-137.

Christensen, H., and V. Nikolaev. (2012). Capital versus performance covenants in debt contracts. Journal of Accounting Research 50 (1): 75-116.

Clogg, C., E. Petkova, and A. Haritou. (1995). Statistical methods for comparing regression coefficients between models. American Journal of Sociology 100 (5): 1261-1293.

Cunningham, L., B. Johnson, E. Johnson, and L. Lisic. (2019). The switch up: An examination of changes in earnings management after receiving SEC comment letters. Contemporary Accounting Research 37 (2): 917-944.

Dechow, P., W. Ge, and C. Schrand. (2010). Understanding earnings quality: A review of the proxies, their determinants and their consequences. Journal of Accounting and Economics 50 (2-3): $344-401$.

Demerjian, P., and E. Owens. (2016). Measuring the probability of financial covenant violation in private debt contracts. Journal of Accounting and Economics 61 (2-3): 433-447.

Demiroglu, C., and C. James. (2010). The information content of bank loan covenants. Review of Financial Studies 23 (10): 3700-3737.

Drake, M., D. Roulstone, and J. Thornock. (2015). The determinants and consequences of information acquisition via EDGAR. Contemporary Accounting Research 32 (3): 1128-1161.

Dye, R. (1985). Disclosure of nonproprietary information. Journal of Accounting Research 23 (1): 123-145.

Ege, M., J. Glenn, and J. Robinson. (2019). Unexpected SEC resource constraints and comment letter quality. Contemporary Accounting Research 37 (1): 33-67.

Frankel, R., M. McNichols, and G. Wilson. (1995). Discretionary disclosure and external financing. The Accounting Review 70 (1): 135-150. 
Georgiev, G. (2017). Too big to disclose: Firm size and materiality blindspots in securities regulation. UCLA Law Review 64 (3): 602-682.

Gorton, G., and A. Winton. (2003). Chapter 8 - financial intermediation. In Handbook of the economics of finance, ed. George M. Constantinides, Milton Harris, René M. Stulz, Volume 1, Part A, 431-552. Elsevier. https://doi.org/10.1016/S1574-0102(03)01012-4. ISSN 1574-0102, ISBN 9780444513625.

Graham, J., S. Li, and J. Qiu. (2008). Corporate misreporting and bank loan contracting. Journal of Financial Economics 89: 4-61.

Gunny, K., and J. Hermis. (2019). How busyness influences SEC compliance activities: Evidence from the filing review process and comment letters. Contemporary Accounting Research 37: 7-32.

Heese, J., M. Khan, and K. Ramanna. (2017). Is the SEC captured? Evidence from comment-letter reviews. Journal of Accounting and Economics 64 (1): 98-122.

Hirshleifer, D., and S. Teoh. (2003). Limited attention, information disclosure, and financial reporting. Journal of Accounting and Economics 36 (1-3): 337-386.

Huang, A., R. Lehavy, A. Zang, and R. Zheng. (2018). Analyst information discovery and interpretation roles: A topic modeling approach. Management Science 64 (6): 2833-2855.

Ivashina, V., and B. Vallee. (2020). Weak credit covenants. National Bureau of economic research working paper no. w27316, Available at: https:/www.nber.org/papers/w27316. Issue Date June 2020.

Johnston, R., and R. Petacchi. (2017). Regulatory oversight of financial reporting: Securities and exchange commission comment letters. Contemporary Accounting Research 34 (2): 1128-1155.

Jung, W., and Y. Kwon. (1988). Disclosure when the market is unsure of information endowment of managers. Journal of Accounting Research 26 (1): 146-153.

Kothari, S., S. Shu, and P. Wysocki. (2009). Do managers withhold bad news? Journal of Accounting Research 47 (1): 241-276.

Kross, W., B. Ro, and D. Schroeder. (1990). Earnings expectations: The analysts' information advantage. The Accounting Review 65 (2): 461-476.

Kubick, T., D. Lynch, M. Mayberry, and T. Omer. (2016). The effects of regulatory scrutiny on tax avoidance: An examination of SEC comment letters. The Accounting Review 91 (6): 1751-1780.

Lang, M., and R. Lundholm. (1993). Cross-sectional determinants of analyst ratings of corporate disclosures. Journal of Accounting Research 31 (2): 246-271.

Lerman, A., and J. Livnat. (2010). The new form 8-K disclosures. Review of Accounting Studies 15 (4): $752-$ 778.

Li, E. (2013). Revealing future prospects without forecasts: The case of accelerating material contract filings. The Accounting Review 88 (5): 1769-1804.

Loughran, T., and B. McDonald. (2017). The use of EDGAR filings by investors. Journal of Behavioral Finance 18 (2): 231-248.

Plumlee, M., Y. Xie, M. Yan, and J. Yu. (2015). Bank loan spread and private information: Pending approval patents. Review of Accounting Studies 20 (2): 593-638.

Rajan, R. (1992). Insiders and outsiders: The choice between informed and Arm's length debt. Journal of Finance 47 (4): 1367-1400.

Roberts, M. (2015). The role of dynamic renegotiation and asymmetric information in financial contracting. Journal of Financial Economics 116 (1): 61-81.

Robinson, J., Y. Xue, and Y. Yu. (2011). Determinants of disclosure noncompliance and the effect of the SEC review: Evidence from the 2006 mandated compensation disclosure regulations. The Accounting Review 86 (4): $1415-1444$.

Ryans, J. (2017). Using the EDGAR log file data set. Working paper. Available at: https://papers.ssrn.com/ sol3/papers.cfm?abstract_id=2913612. Revised February 17, 2017.

Saavedra, D. (2018). Syndicate size and the choice of covenants in debt contracts. The Accounting Review 93 (6): $301-329$.

Saavedra, D. (2019a). Do lenders influence borrowers' mandatory disclosures? Evidence from redacted credit agreements. Working paper. Available at: https://ssrn.com/abstract=3500592. Revised December 30, 2019.

Saavedra, D. (2019b). How do debt contracts allocate control over unforeseen investment decisions? Working paper. Available at: https://ssrn.com/abstract=3179705. Revised July 9, 2019.

Schwartz, K., and B. Soo. (1996). Evidence of regulatory noncompliance with SEC disclosure rules on auditor changes. The Accounting Review 71 (4): 555-572.

Sengupta, P. (1998). Corporate disclosure quality and the cost of debt. The Accounting Review 73 (4): 459474.

Skinner, D. (1994). Why firms voluntarily disclose bad news. Journal of Accounting Research 32 (1): $38-60$. 
Skinner, D. (1997). Earnings disclosures and stockholder lawsuits. Journal of Accounting and Economics 23 (3): 249-282.

Standard \& Poors. (2011). A Guide to the Loan Market. https://www.lcdcomps.com/d/pdf/LoanMarketguide. pdf.

Sufi, A. (2007). Information asymmetry and financial arrangements: Evidence from syndicated loans. Journal of Finance 62 (2): 629-668.

Tian, X., and M. Yu (2018, August). Redact when competitors act-examining the threat of rivals' product portfolio modifications. Available at SSRN: https://papers.ssrn.com/sol3/papers.cfm?abstract_id= 3224192. Revised May 8, 2018.

Verrecchia, R. (1990). Endogenous proprietary costs through firm interdependence. Journal of Accounting and Economics 12 (1-3): 245-251.

Verrecchia, R., and J. Weber. (2006). Redacted disclosure. Journal of Accounting Research 44 (4): 791-814.

Wittenberg-Moerman, R. (2008). The role of information asymmetry and financial reporting quality in debt trading: Evidence from the secondary loan market. Journal of Accounting and Economics 46 (2-3): 240260.

Yu, J. (2013). Loan spreads and unexpected earnings. Working paper. Available at: https://ssrn.com/abstract= 2333661. Revised September 30, 2013.

Publisher's note Springer Nature remains neutral with regard to jurisdictional claims in published maps and institutional affiliations. 